Prepared in cooperation with the National Park Service

Denitrification Rates in Marsh Soils and Hydrologic and Water Quality Data for Northeast Creek and Bass Harbor Marsh Watersheds, Mount Desert Island, Maine

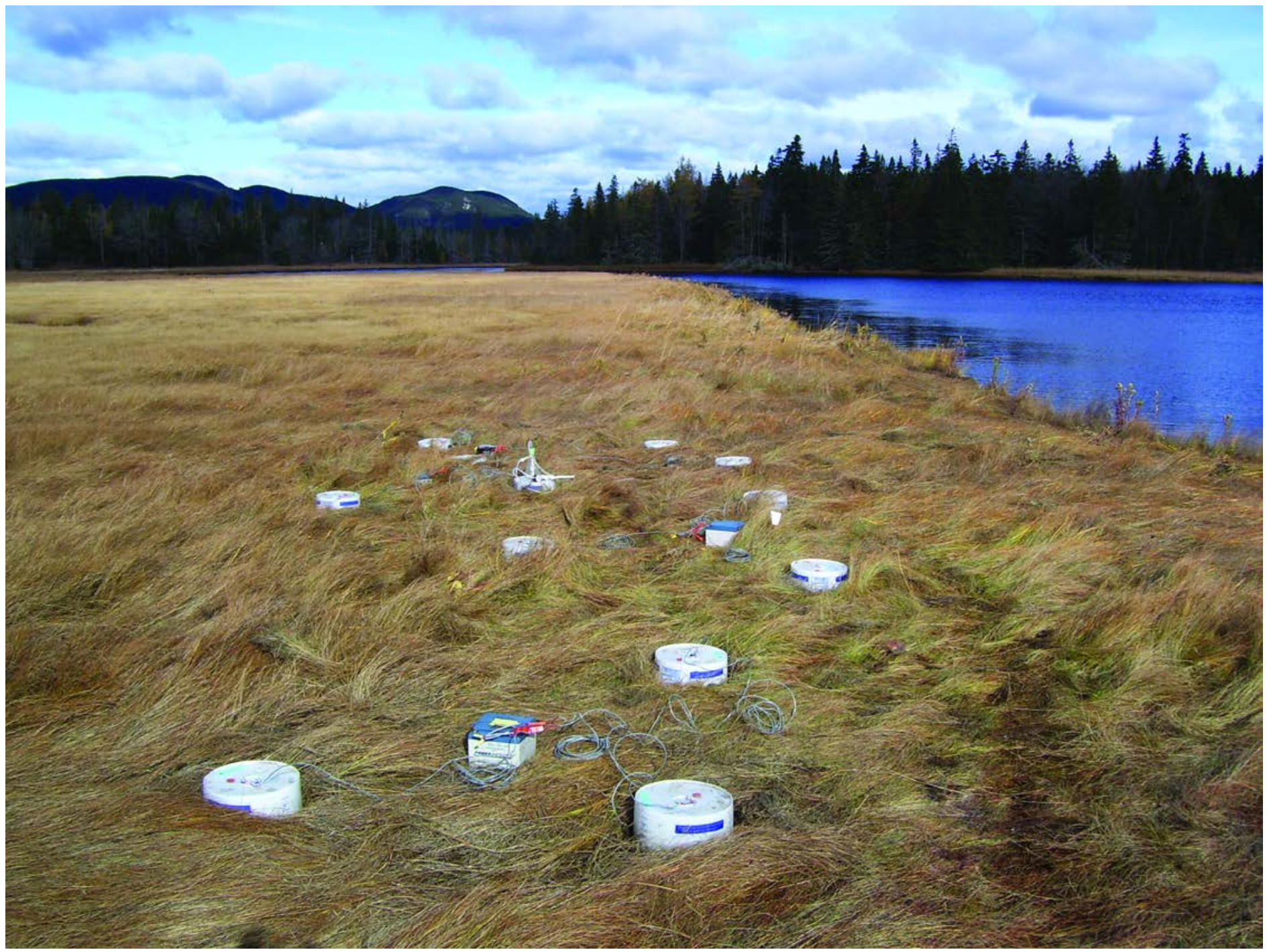

Open-File Report 2011-1252 
Cover. Denitrification measurement site in Bass Harbor Marsh, Acadia National Park, Mount Desert Island, Maine showing chambers installed in the marsh soil used to measure the accumulation of nitrous oxide $\left(\mathrm{N}_{2} \mathrm{O}\right)$ in the chamber headspace. The batteries shown are used to power small fans in each chamber to maintain well mixed gases in the chambers. 


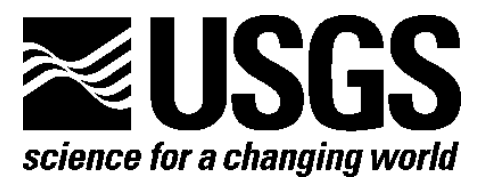

In cooperation with the National Park Service

\section{Denitrification Rates in Marsh Soils and Hydrologic and Water-Quality Data for Northeast Creek and Bass Harbor Marsh watersheds, Mount Desert Island, Maine}

By Thomas G. Huntington, Charles W. Culbertson, and John H. Duff

Open-File Report 2011-1252

U.S. Department of the Interior

U.S. Geological Survey 


\section{U.S. Department of the Interior \\ KEN SALAZAR, Secretary}

\section{U.S. Geological Survey \\ Marcia K. McNutt, Director}

U.S. Geological Survey, Reston, Virginia 2011

For product and ordering information:

World Wide Web: http://www.usgs.gov/pubprod

Telephone: 1-888-ASK-USGS

For more information on the USGS-the Federal source for science about the Earth,

its natural and living resources, natural hazards, and the environment:

World Wide Web: http://www.usgs.gov

Telephone: 1-888-ASK-USGS

Suggested citation:

Huntington, T.G., Culbertson, C.W., and Duff, J.H., 2011, Denitrification rates in marsh soils and hydrologic and water quality data for Northeast Creek and Bass Harbor Marsh watersheds, Mount Desert Island, Maine: U.S. Geological Survey Open-File Report 2011-1252, 28 p. at http://pubs.usgs.gov/of/2011/1252/.

Any use of trade, product, or firm names is for descriptive purposes only and does not imply endorsement by the U.S. Government.

Although this report is in the public domain, permission must be secured from the individual copyright owners to reproduce any copyrighted material contained within this report. 


\section{Acknowledgements}

The authors are grateful for the support they received from several people that contributed to the successful completion of this study. Staff at Acadia National Park (David Manski and Bill Gawley) helped facilitate this study from the initial conceptualization through its completion. Staff at the U.S. Geological Survey, Maine Water Science Center (James Caldwell, Charles Schalk, Laura Flight, and Greg Stewart) provided assistance with groundwater level data processing and interpretation, overall data review, and data uploading into the Survey's National Water Information System database. Lynn Bartsch and James Caldwell, both with the U.S. Geological Survey, provided technical reviews that improved the report. 


\section{Contents}

Abstract

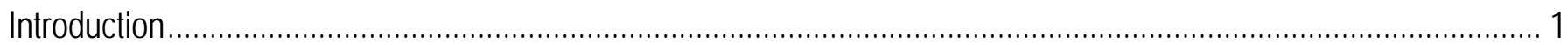

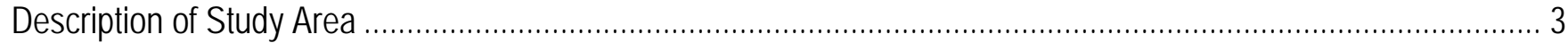

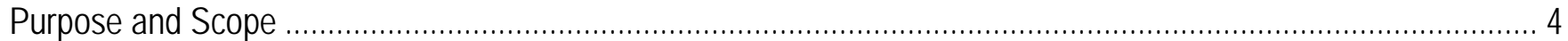

Data Collection Methods

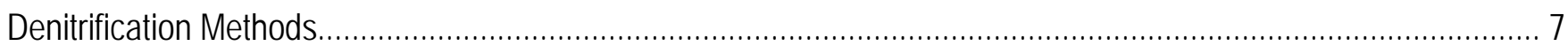

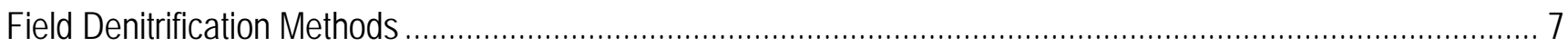

Laboratory Denitrification Methods ........................................................................................................ 9

Laboratory Methods and Computation of $\mathrm{N}_{2} \mathrm{O}$ Release Rate ................................................................14

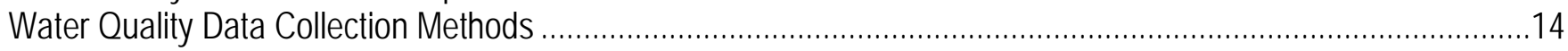

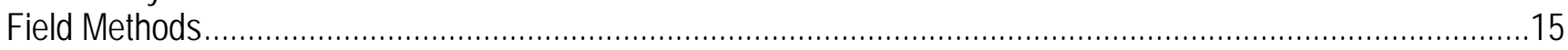

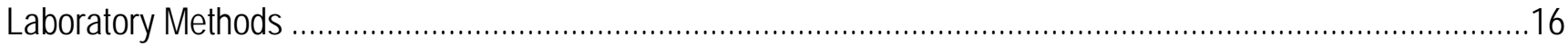

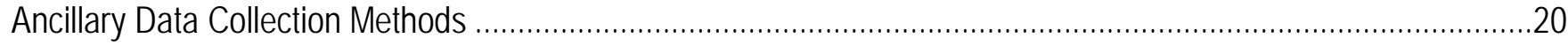

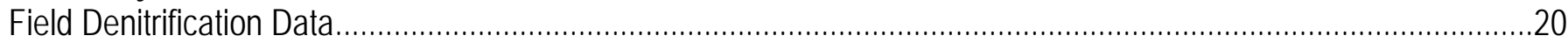

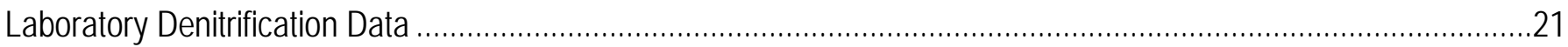

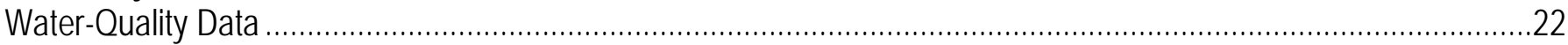

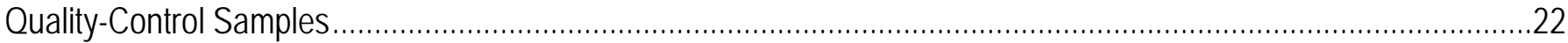

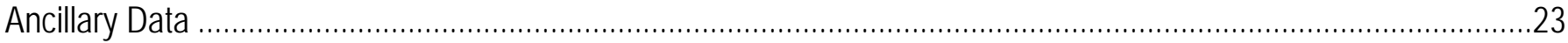

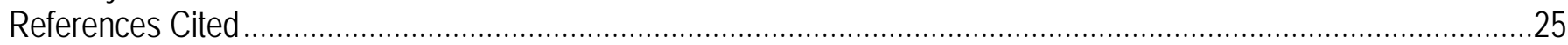

\section{Figures}

Figure 1. Shaded relief site map showing locations of the study areas that include Northeast Creek (NEC) and Bass Harbor Marsh (BHM) watersheds on Mount Desert Island, Maine............................................................. 4

Figure 2. Map showing the Northeast Creek watershed area, Mount Desert Island, Maine, and surface-water

sampling locations on the major tributaries and the location of a groundwater monitoring well................................. 5

Figure 3. Map showing the location of Bass Harbor Marsh watershed, Mount Desert Island, Maine, and surface-

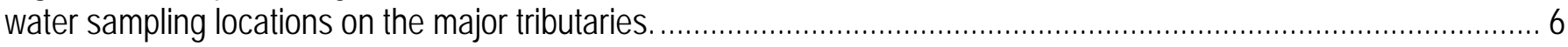

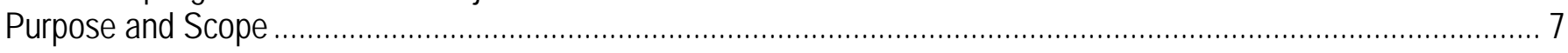

Figure 4. Aerial photograph showing the locations of denitrification measurement sites and groundwater sampling wells in Northeast Creek watershed, Mount Desert Island, Maine.

Figure 5. Aerial photograph showing the locations of denitrification measurement sites and groundwater sampling wells in Bass Harbor Marsh watershed, Mount Desert Island, Maine.

Figure 6. Graphs showing A, Water level in Fresh Meadow Marsh, Northeast Creek watershed, Mount Desert Island, Maine and discharge at Otter Creek USGS station ID 01022840 and B, daily precipitation at McFarland Hill Station, near Bar Harbor, Mount Desert Island, Maine.

\section{Tables}

Table 1. Dates of field (in situ) denitrification rate measurements, locations of measurements and treatments applied on those measurement dates.

Table 2. Surface water and groundwater water-quality monitoring stations in Northeast Creek and Bass Harbor Marsh watersheds sampled in 2008 and 2009

Table 3. Constituent name, U.S. Geological Survey National Water Information System parameter codes and method codes, and minimum reporting limits for temperature, specific conductance, dissolved oxygen, and nutrients 
Tables 4-27 (links to Excel files tables 4-27 are in text)

Table 4. Denitrification rate measurements for June 2008

Table 5. Denitrification rate measurements for July 2008

Table 6. Denitrification rate measurements for August 2008

Table 7. Denitrification rate measurements for September 2008

Table 8. Denitrification rate measurements for October 2008

Table 9. Denitrification rate measurements for June 2009

Table 10. Denitrification rate measurements for July 2009

Table 11. Denitrification rate measurements for August 2009

Table 12. Denitrification rate measurements for September 2009

Table 13. Water, organic matter, and dry weight fractions (by weight) of marsh soils.

Table 14. Laboratory incubation denitrification rate measurements for May 5, 2009

Table 15. Laboratory incubation denitrification rate measurements for May 7, 2009

Table 16. Laboratory incubation denitrification rate measurements for May 13, 2009

Table 17. Laboratory incubation denitrification rate measurements for May 15. 2009

Table 18. Laboratory incubation denitrification rate measurements for May 20, 2009

Table 19. Laboratory incubation denitrification rate measurements for May 22, 2009

Table 20. Laboratory incubation denitrification rate measurements for May 27, 2009

Table 21. Laboratory incubation denitrification rate measurements for May 29, 2009

Table 22. Laboratory incubation denitrification rate measurements for June 2, 2009

Table 23. Nutrient water-quality data for stream water samples

Table 24. Field measurements of temperature and specific conductance for stream water samples

Table 25. Nutrient water-quality data for groundwater samples collected from NEC watershed

Table 26. Nutrient water-quality data for groundwater samples collected from BHM watershed

Table 27. Field measurements of temperature and specific conductance for groundwater samples 


\section{Conversion Factors}

Inch/Pound to SI

\begin{tabular}{|c|c|c|}
\hline Multiply & By & To obtain \\
\hline \multicolumn{3}{|c|}{ Length } \\
\hline inch (in.) & 2.54 & centimeter $(\mathrm{cm})$ \\
\hline mile (mi) & 1.609 & kilometer (km) \\
\hline inch (in.) & 25.4 & millimeter $(\mathrm{mm})$ \\
\hline foot $(\mathrm{ft})$ & 0.3048 & meter $(\mathrm{m})$ \\
\hline inch (in.) & $3.937 * 10^{-5}$ & micron $(\mu)$ \\
\hline \multicolumn{3}{|c|}{ Area } \\
\hline acre & 4,047 & square meter $\left(\mathrm{m}^{2}\right)$ \\
\hline square mile $\left(\mathrm{mi}^{2}\right)$ & 2.590 & square kilometer $\left(\mathrm{km}^{2}\right)$ \\
\hline square foot $\left(\mathrm{ft}^{2}\right)$ & 0.09290 & square meter $\left(\mathrm{m}^{2}\right)$ \\
\hline \multicolumn{3}{|c|}{ Volume } \\
\hline gallon (gal) & 3.785 & liter (L) \\
\hline ounce, fluid (fl. oz)) & 29.57 & milliliter $(\mathrm{mL})$ \\
\hline cubic inch $\left(\mathrm{in}^{3}\right)$ & 16.39 & cubic centimeter $\left(\mathrm{cm}^{3}\right)$ \\
\hline \multicolumn{3}{|c|}{ Mass } \\
\hline ounce, avoirdupois (oz) & 28.35 & $\operatorname{gram}(\mathrm{g})$ \\
\hline ounce, avoirdupois (oz) & 0.02835 & milligram (mg) \\
\hline \multicolumn{3}{|c|}{ Application rate } \\
\hline $\begin{array}{l}\text { ounce, avoirdupois (oz) per square } \\
\text { yard }\left[\left(\mathrm{oz} / \mathrm{yd}^{2}\right]\right.\end{array}$ & 0.02949 & $\begin{array}{l}\text { grams per square meter } \\
\left(\mathrm{g} / \mathrm{m}^{2}\right)\end{array}$ \\
\hline
\end{tabular}

Temperature in degrees Celsius $\left({ }^{\circ} \mathrm{C}\right)$ may be converted to degrees Fahrenheit $\left({ }^{\circ} \mathrm{F}\right)$ as follows:

$$
{ }^{\circ} \mathrm{F}=\left(1.8 x^{\circ} \mathrm{C}\right)+32
$$

Temperature in degrees Fahrenheit $\left({ }^{\circ} \mathrm{F}\right)$ may be converted to degrees Celsius $\left({ }^{\circ} \mathrm{C}\right)$ as follows:

$$
{ }^{\circ} \mathrm{C}=\left({ }^{\circ} \mathrm{F}-32\right) / 1.8
$$

Vertical coordinate information is referenced to the North American Vertical Datum of 1988 (NAVD 88).

Horizontal coordinate information is referenced to the North American Datum of 1983 (NAD 83).

Altitude, as used in this report, refers to distance above the vertical datum.

Specific conductance is given in microsiemens per centimeter at 25 degrees Celsius $\left(\mu \mathrm{S} / \mathrm{cm}\right.$ at $\left.25^{\circ} \mathrm{C}\right)$.

Concentrations of chemical constituents in water are given either in milligrams per liter (mg/L) or micrograms per liter $(\mu \mathrm{g} / \mathrm{L})$. 


\section{List of Acronyms}

$\begin{array}{ll}\text { ANP } & \text { Acadia National Park } \\ \text { BHM } & \text { Bass Harbor Marsh } \\ \text { DIN } & \text { dissolved inorganic nitrogen } \\ \text { GC-ECD } & \text { gas chromatography electron capture detection } \\ \text { NADP } & \text { National Atmospheric Deposition Program } \\ \text { NEC } & \text { Northeast Creek } \\ \text { NETN } & \text { Northeast Temperate Network } \\ \text { NOAA } & \text { National Oceanic and Atmospheric Administration } \\ \text { NWQL } & \text { National Water Quality Laboratory } \\ \text { OM } & \text { organic matter } \\ \text { RPD } & \text { relative percent differences } \\ \text { SE } & \text { standard error } \\ \text { UHP } & \text { ultra high purity } \\ \text { USGS } & \text { U.S. Geological Survey } \\ \text { WHOI } & \text { Woods Hole Oceanographic Institution }\end{array}$


This page has been left blank intentionally. 


\title{
Denitrification Rates in Marsh Soils and Hydrologic and Water-Quality Data for Northeast Creek and Bass Harbor Marsh watersheds, Mount Desert Island, Maine
}

\author{
by Thomas G. Huntington, Charles W. Culbertson, and John H. Duff
}

\begin{abstract}
Nutrient enrichment from atmospheric deposition, agricultural activities, wildlife, and domestic sources is a concern at Acadia National Park because of the potential problem of waterquality degradation and eutrophication in estuaries. Water-quality degradation has been observed at the park's Bass Harbor Marsh estuary but minimal degradation is observed in the Northeast Creek estuary. Previous studies at Acadia National Park have estimated nutrient inputs to estuaries from atmospheric deposition and surface-water runoff and have identified shallow groundwater as an additional potential nutrient source. Previous studies at Acadia National Park have assumed that a certain fraction of the nitrogen input was removed through microbial denitrification, but rates of denitrification (natural or maximum potential) in marsh soils have not been determined. The U.S. Geological Survey, in cooperation with Acadia National Park, measured in situ denitrification rates in marsh soils in Northeast Creek and Bass Harbor Marsh watersheds during the summer seasons of 2008 and 2009. Denitrification was measured under ambient conditions and following inorganic nitrogen and glucose additions. Laboratory incubations of marsh soils with and without acetylene were conducted to determine average ratios of nitrous oxide to nitrogen produced during denitrification. Surface water and groundwater samples were analyzed for nutrients, specific conductance, temperature, and dissolved oxygen. Water levels were recorded continuously during the growing season in the Fresh Meadow Marsh in the Northeast Creek watershed.
\end{abstract}

\section{Introduction}

Acadia National Park (ANP) was created to protect the natural beauty of the only rocky headlands along the U.S. Atlantic coast. Fundamental to this purpose is protection of the ecological, scientific, and scenic attributes of Acadia's coastal ecosystems. Over 10 percent of the Park's land area is classified as wetland (Calhoun and others, 1994). A diverse array of wetland types are represented, including forested and scrub-shrub wetlands, freshwater emergent marshes, peatlands, and salt marshes (Roman and others, 2001). Acadia's estuaries provide unique fish and wildlife habitats within the Park. The estuaries are valuable as nursery grounds for coastal fish species and foraging habitat for wetland and aquatic birds. Estuaries also act as "filters" for water that ultimately enters the nearshore zone, thus helping to maintain coastal water quality (Herbert, 1999). Tidally exported productivity from salt marsh or wetland plant communities can have a profound effect on estuarine productivity, making coastal salt marshes 
and wetlands among the most productive ecosystems in North America. Changes in sediment physicochemical conditions related to nutrient enrichment or perturbations due to human activity can alter the pattern of plant zonation, whereby highly competitive invasive plant species can potentially displace native plant species (Burke and others, 2002). Shoreline development and agricultural runoff also threatens the sustainability of salt marsh ecosystems throughout the northeastern U.S. (Silliman and Bertness, 2004; Fitch and others, 2009).

Acadia's Water Resources Management Plan (Acadia National Park, 2000) identifies accelerated rates of freshwater and coastal marine eutrophication as a priority water quality issue and one of the Park's most important resource management challenges. Residential development outside the park boundary is increasing at an unprecedented rate. For example, between 1981 and 2001 the number of homes in the combined drainage basins of Aunt Betseys Creek, French Hill Brook, Old Mill Brook, and Stony Book in the Northeast Creek (NEC) watershed increased from 83 to 279 (Nielsen 2002a, 2002b). Recent studies show that Acadia's Bass Harbor Marsh (BHM) estuary is already tending towards a eutrophic state (Doering and others, 1995; Kinney and Roman, 1998). Evidence from many other Atlantic Coast estuarine systems indicates that land clearing and subsequent septic system installation and lawn fertilizer application are likely to increase nutrient loads of both groundwater and surface water entering the estuary (Valiela and others, 1990, 2000; Howes and others, 1996; Bricker and others, 1999; Cloern, 2001; National Research Council, 2000; Valiela and Bowen, 2002; Tobias and others, 2001; Harvey and Odum, 1990).

The chief nutrient of concern for eutrophication within Acadia's estuaries is nitrogen. Nitrogen inputs to the NEC and BHM watersheds and estuaries are derived from several sources including atmospheric deposition, septic effluent, tidal inputs, urban/agricultural runoff, and wildlife. Net mineralization of soil organic nitrogen can also contribute dissolved nitrogen species. Previous studies have quantified inputs from atmospheric deposition and surface water for NEC (Nielsen, 2002b), and BHM (Doering and others, 1995), but inputs from groundwater and tidal sources have not been determined. Rates of denitrification (natural or maximum potential) in marsh soils have not been determined in previous studies at ANP.

Previous studies at Acadia National Park have assumed that a certain fraction of the nitrogen input was removed through microbial denitrification, but rates of denitrification (natural or maximum potential) in marsh soils have not been determined. Denitrification is the process of microbial conversion of nitrate to nitrogen $\left(\mathrm{N}_{2}\right)$ and nitrous oxide $\left(\mathrm{N}_{2} \mathrm{O}\right)$ gases. Denitrification rate is measured indirectly as the $\mathrm{N}_{2} \mathrm{O}$ production rate. In the $\mathrm{NEC}$ and $\mathrm{BHM}$ watershed we assume that most denitrification occurs in the marsh soils and estuarine sediments as has been observed in other coastal wetlands (Seitzinger and Nixon, 1985; Seitzinger 1988; Day and others, 1989). Denitrification rates increase with increasing nitrogen loading (Seitzinger and others, 1984; Seitzinger and Kroeze, 1998; Wigand and others, 2004) and have been shown to be seasonally and diurnally dependent, governed principally by temperature, supply of nitrate, and availability of organic carbon (Smith and others, 1985; Jorgensen and Sorenson, 1988).

Denitrification rates are highly variable and must be measured in situ to determine ambient rates and maximum potential rates. 


\section{Description of Study Area}

Northeast Creek (NEC) is a small microtidal estuary in the northeastern part of Mount Desert Island, Maine, that is experiencing increasing residential development in the watershed (fig. 1). The NEC watershed [26.02 square kilometers $\left.\left(\mathrm{km}^{2}\right)\right]$ is composed of several subwatersheds (fig. 2). A partial flow restriction near the estuary outlet results in tidal inundation of most wetland sediments only during high spring tides. Recent studies have suggested that deep groundwater in the underlying fractured bedrock is not a significant term in the freshwater budget for NEC (Nielsen, 2002a). Shallow groundwater discharge is a potential mechanism for the delivery of dissolved nitrogen species from domestic septic systems and fertilizer to estuaries that can result in eutrophication (Valiela and others, 1990; Reay and others, 1992; Portnoy and others, 1998; Valiela and Bowen, 2002). Shallow groundwater can enter the wetland, and eventually the estuary, through seepage zones at the upland/wetland boundary or it can enter the estuary directly through the creek bottom/banks (Howes and others, 1996; Portnoy and others, 1998). Culbertson and others (2007) identified groundwater seeps in NEC and BHM using aerial thermal imagery and continuous and discrete measurements of temperature and specific conductance in selected seeps, but their relative contribution to total inputs is not known.

The BHM watershed $\left(21.78 \mathrm{~km}^{2}\right)$, in the southwestern part of Mount Desert Island, is composed of several sub-watersheds (fig. 3), the largest of which, Marshall Brook, lies outside Park boundaries and is substantially impacted by residential and commercial development, and a former landfill. Signs of eutrophication in BHM estuary, the largest tidal marsh estuary on the island, were documented more than a decade ago (Doering and others, 1995). Evidence of a continued eutrophication response to nutrient inputs from within the watershed and from oceanic sources to BHM is noted in more recent studies (Kinney and Roman, 1998; Farris and Oviatt, 1999). A 1999-2000 study (Nielsen and others, 2002) corroborated the findings of Doering and others (1995) that freshwater dissolved inorganic nitrogen (DIN) comprises a significant portion of the total nitrogen load to BHM from Marshall and Heath Brooks; organic N comprised most of the total $\mathrm{N}$ pool in the other tributaries feeding BHM estuary (Doering and others, 1995). 


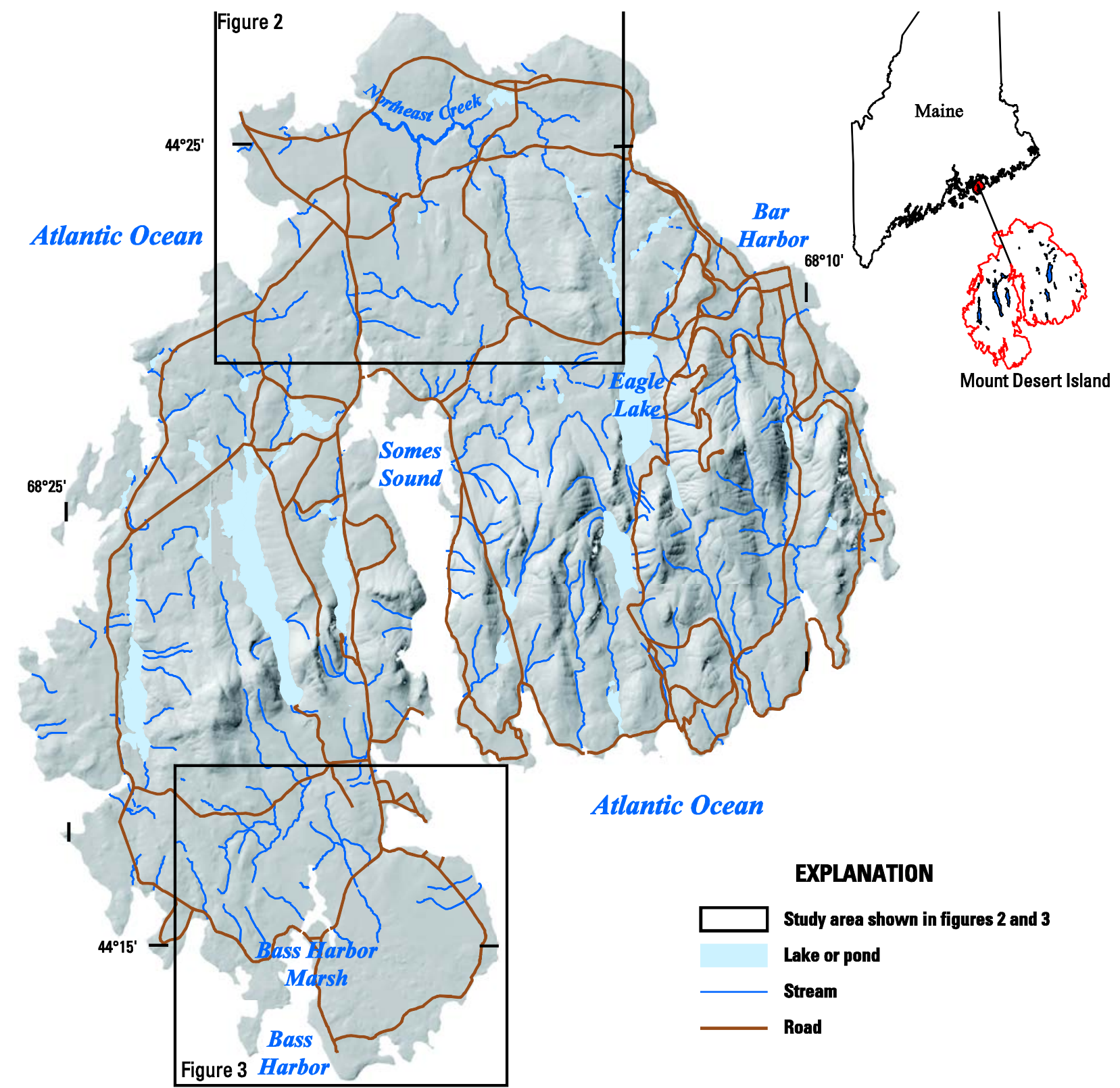

Base from U.S. Geological Sunvey digital line graph, 1:100,000 Bar Harbor, 1985

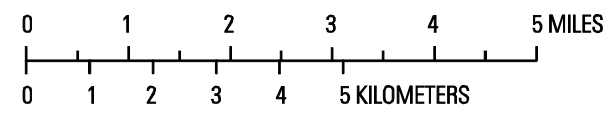

Figure 1. Shaded relief site map showing locations of the study areas that include Northeast Creek (NEC) and Bass Harbor Marsh (BHM) watersheds on Mount Desert Island, Maine. 


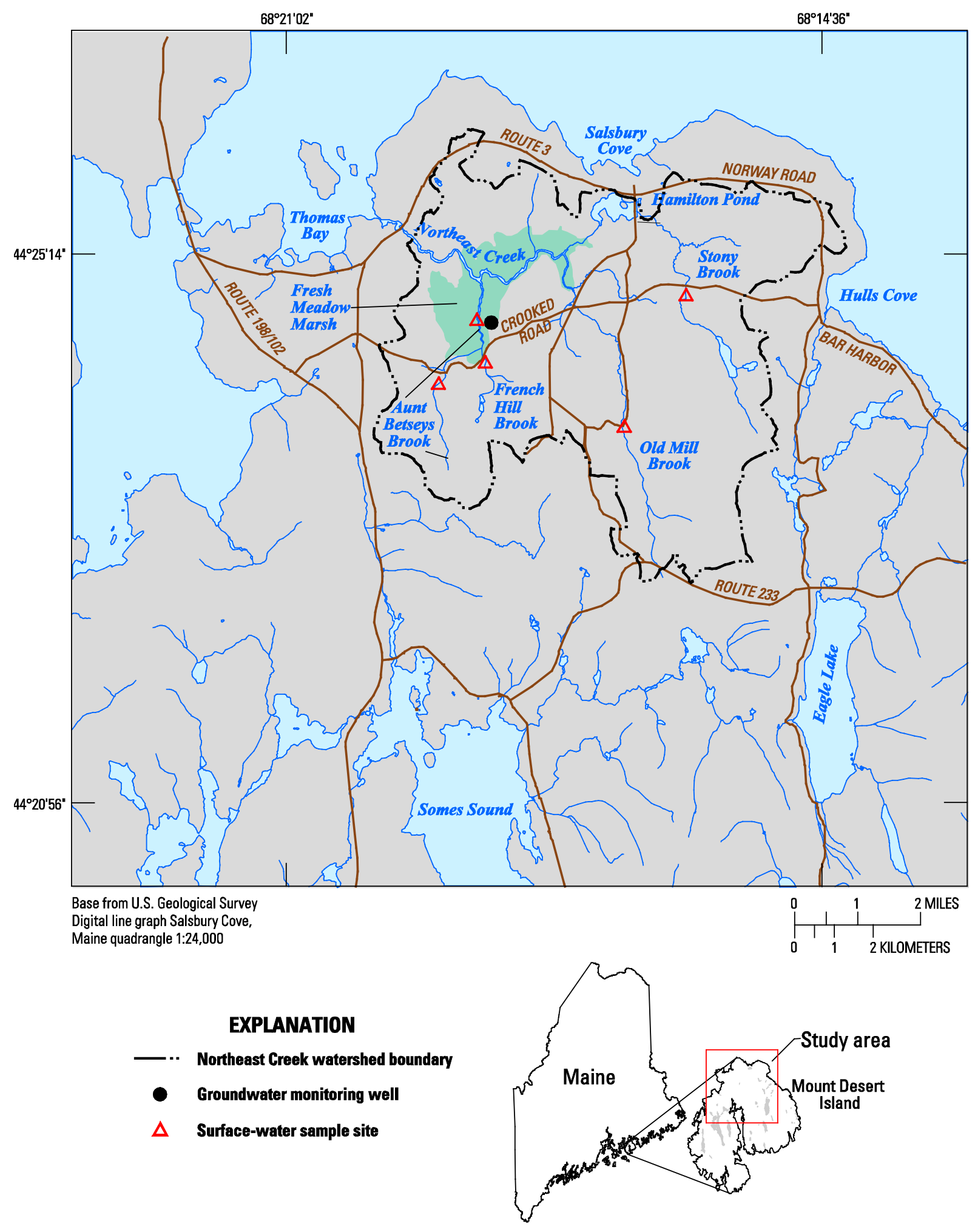

Figure 2. Map showing the Northeast Creek watershed area, Mount Desert Island, Maine, and surface-water sampling locations on the major tributaries and the location of a groundwater monitoring well. 


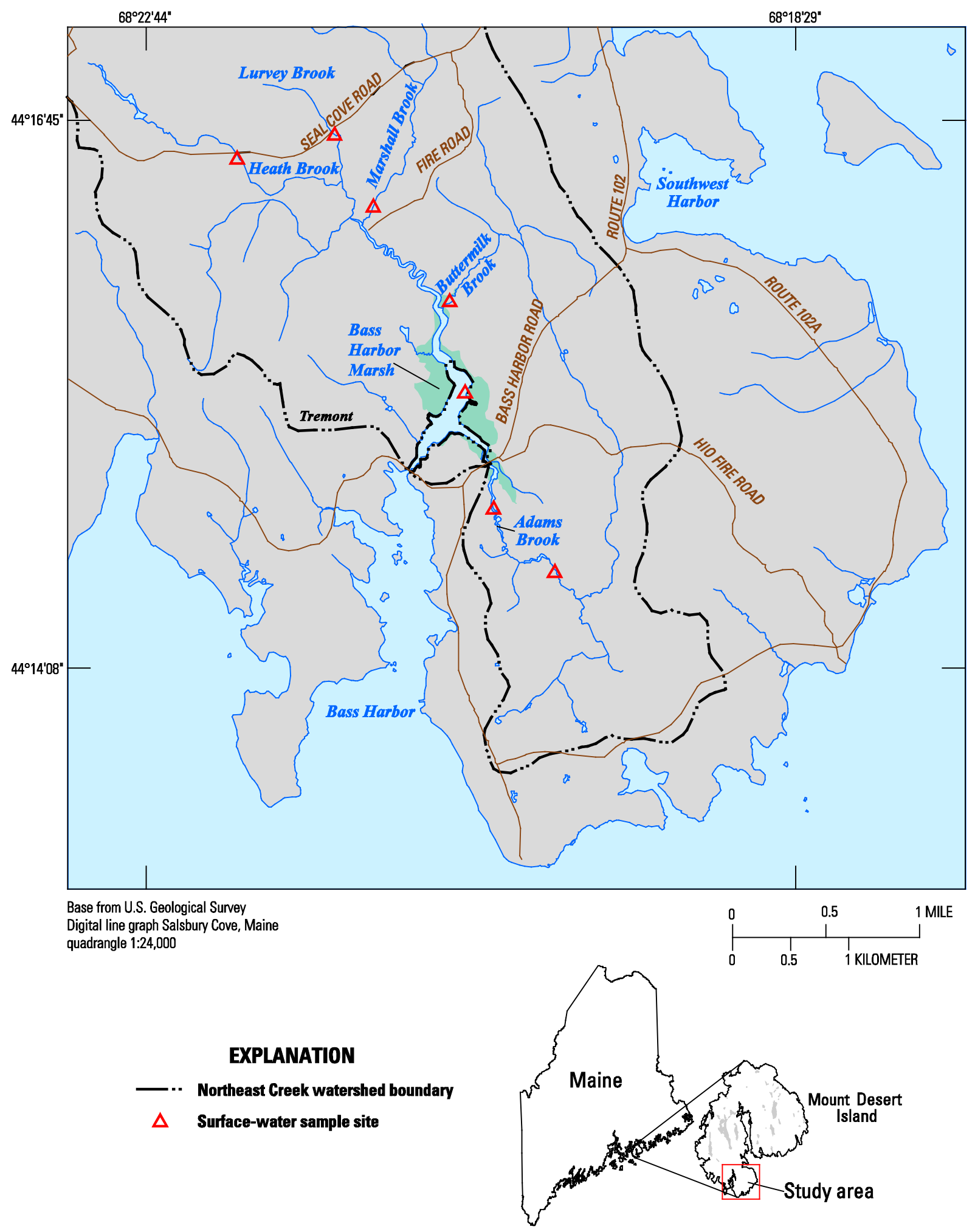

Figure 3. Map showing the location of Bass Harbor Marsh watershed, Mount Desert Island, Maine, and surface-water sampling locations on the major tributaries. 
This report provides the data collected by the U.S. Geological Survey(USGS), in cooperation with Acadia National Park, as part of a study to measure in situ denitrification rates in marsh soils in Northeast Creek and Bass Harbor Marsh watersheds during the summer seasons of 2008 and 2009. Field and laboratory data are also provided that report rates of $\mathrm{N}_{2} \mathrm{O}$ release from soils following additions of various rates of nitrate and with and without the addition of glucose. Laboratory incubation data are also provided that report rates of $\mathrm{N}_{2} \mathrm{O}$ production with and without the acetylene block that will permit calculation of the ratio of $\mathrm{N}_{2}$ to $\mathrm{N}_{2} \mathrm{O}$ produced during denitrification in future studies. These ratios are not presented in this open file report. Surface water and groundwater nutrient chemical analysis data and specific conductance, temperature, and dissolved oxygen data are also included in this report. This report also provides groundwater level data that was recorded continuously during the growing season in Fresh Meadow Marsh in the Northeast Creek Watershed.

\section{Data Collection Methods}

Data collection methods are subdivided into three sections. The first section describes the methods used for measuring rates of $\mathrm{N}_{2} \mathrm{O}$ release in the field and the laboratory, and it describes the laboratory determination of $\mathrm{N}_{2} \mathrm{O}$ by gas chromatography. The second section describes the methods used for water quality sampling, filtration, and laboratory methods of chemical analysis. The final section describes the methods used for recording water level continuously.

\section{Denitrification Methods}

Methods for measuring rates of denitrification are described in two sections. The first section describes the static chamber technique used for in situ (field) measurement, the measurement schedule, and the treatments that were applied to assess maximum denitrification rate (denitrification potential). The second section describes the laboratory incubation experiment, the laboratory determinations of $\mathrm{N}_{2} \mathrm{O}$ gas, and the calculation of denitrification rates.

\section{Field Denitrification Methods}

In situ denitrification measurements were made using a static chamber technique where denitrification was estimated from the increase in $\mathrm{N}_{2} \mathrm{O}$ concentration in the headspace of a chamber placed on the marsh sediment surface (Oremland and others, 1984; Meding and others, 2001, Groffman and others, 2006). The flux chambers were constructed from plastic buckets that were 28.4 centimeters $(\mathrm{cm})$ in internal diameter. The chambers were equipped with batteryoperated fans to mix the gas in the headspace and rubber septa for gas sampling. The chambers were installed by pressing them into the marsh soil surface to a depth of $10 \mathrm{~cm}$ to ensure an effective seal so that the $\mathrm{N}_{2} \mathrm{O}$ released from the soil into the headspace could not escape to the ambient air or be mixed with ambient air. The volume of the headspace was recorded during each incubation. Gas samples for $\mathrm{N}_{2} \mathrm{O}$ analysis were collected from the chambers through rubber septa via glass syringes at various time intervals following installation and sealing of the chambers. Gas samples were stored in glass vacutainers (vials) sealed with Teflon lined butyl rubber stoppers. The static chamber technique for measuring soil respiration has been described in Huntington and others (1998). 
Denitrification measurements $\left(\mathrm{N}_{2} \mathrm{O}\right.$ release rate) were made in marsh soils in NEC and BHM (figs. 4 and 5) on the dates shown in table 1 that lists the locations of the flux measurements, whether they were made under ambient conditions or with the additions of nitrate, glucose, or both. Table 1 also reports the rates of nitrate additions where nitrate treatments were applied. Nitrate, glucose, and acetylene treatment additions were performed after the chambers had been installed into the soil to ensure that the additions were confined to the soil below the 28.4-cm diameter chambers to a depth of $10 \mathrm{~cm}$. Treatment solutions of sodium nitrate $\left(\mathrm{NaNO}_{3}\right.$, minimum purity 99 percent, EMD Chemicals, USA) and glucose (minimum 99 percent purity, ACROS Organics, USA) were made from concentrated solutions prepared in the laboratory and diluted in the field with shallow groundwater that was pumped from piezometers at the denitrification measurement sites. One liter (L) of a solution of the indicated nitrate or nitrate plus glucose concentration was added through an opening in the top of the chamber using a funnel. These 1-L additions of $0,5,15,25,50,75,100,250,500$, and 1,000 millimolar nitrate $\left(\mathrm{mM} \mathrm{NO}_{3}\right)$ were equivalent to nitrogen addition rates of $0,1.1,3.3,5.5$, $11,17,22,55,110$, and 221 grams nitrogen per square meter $\left(\mathrm{g} \mathrm{N} \mathrm{m}^{-2}\right)$ respectively. The ' 0 ' nitrate with no glucose addition treatments are referred to as 'ambient' in this report. For treatments where glucose was added, the 1-L treatment solutions contained 75 millimolar $(\mathrm{mM})$ glucose, equivalent to 213 grams per square meter $\left(\mathrm{g} \mathrm{m}^{-2}\right)$ when applied to each chamber. After the treatment addition, a rubber septum was installed in the top of each chamber to ensure a gas tight seal and the fans were started to mix the chamber headspace gases. Acetylene (technical grade, 99.5 percent purity, obtained from Maine Oxy) was bubbled gently into one liter solutions for 2 minutes to saturate the solutions prior to putting these saturated solutions into the chambers.

In most cases, two or three replicate chambers were used to determine average $\mathrm{N}_{2} \mathrm{O}$ production rates at a given location and for a given treatment. For all experimental trials with three or more replicate samples, we calculated the standard error (SE) as a percent of the mean value (SE percent) recorded in the data tables. For the first time period $\left(\mathrm{T}_{0}\right.$ to $\left.\mathrm{T}_{1}\right), 90$ percent of the ambient treatments had SE percent in the range of 2 to 120 percent and the median SE percent was 11 percent. For the first time period $\left(\mathrm{T}_{0}\right.$ to $\left.\mathrm{T}_{1}\right), 90$ percent of the nitrate addition treatments had SE percent in the range of 0.2 to 45 percent and the median SE percent was 9.5 percent. Median SE percent increased during the second time period ( $T_{1}$ to $\left.T_{2}\right)$ to 52 percent in the ambient trials and 16 percent in the nitrate addition trials. There were six denitrification measurement sites in NEC (fig. 4) and six in BHM (fig. 5) where repeated measurements were made over the growing seasons in 2008 and 2009. Flooding during both years limited the number of denitrification measurements that could be made in NEC. Denitrification measurements could not be made with the chamber that we used when there was more than $5 \mathrm{~cm}$ of standing water over the marsh soil surface. 


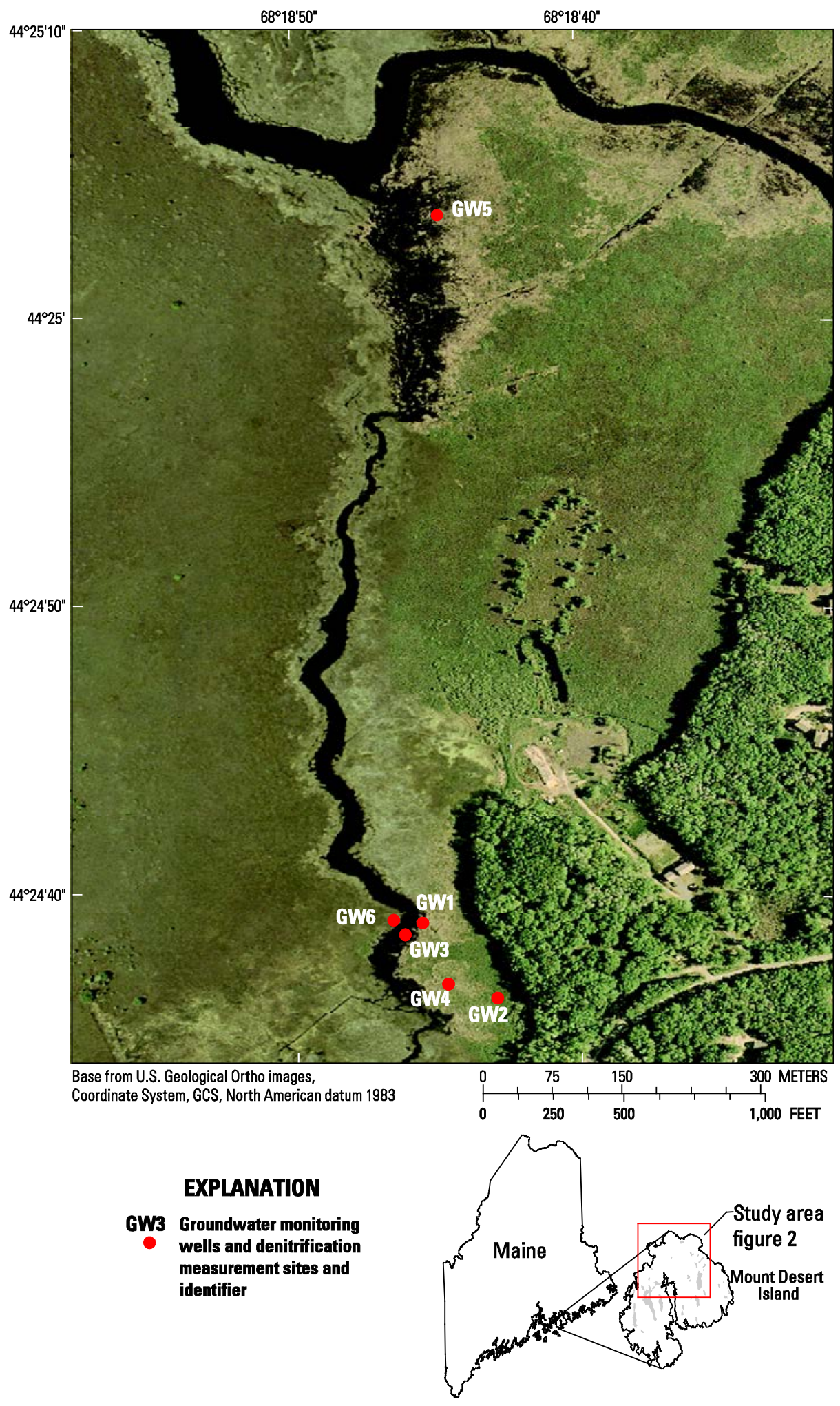

Figure 4. Aerial photograph showing the locations of denitrification measurement sites and groundwater sampling wells in Northeast Creek watershed, Mount Desert Island, Maine. 


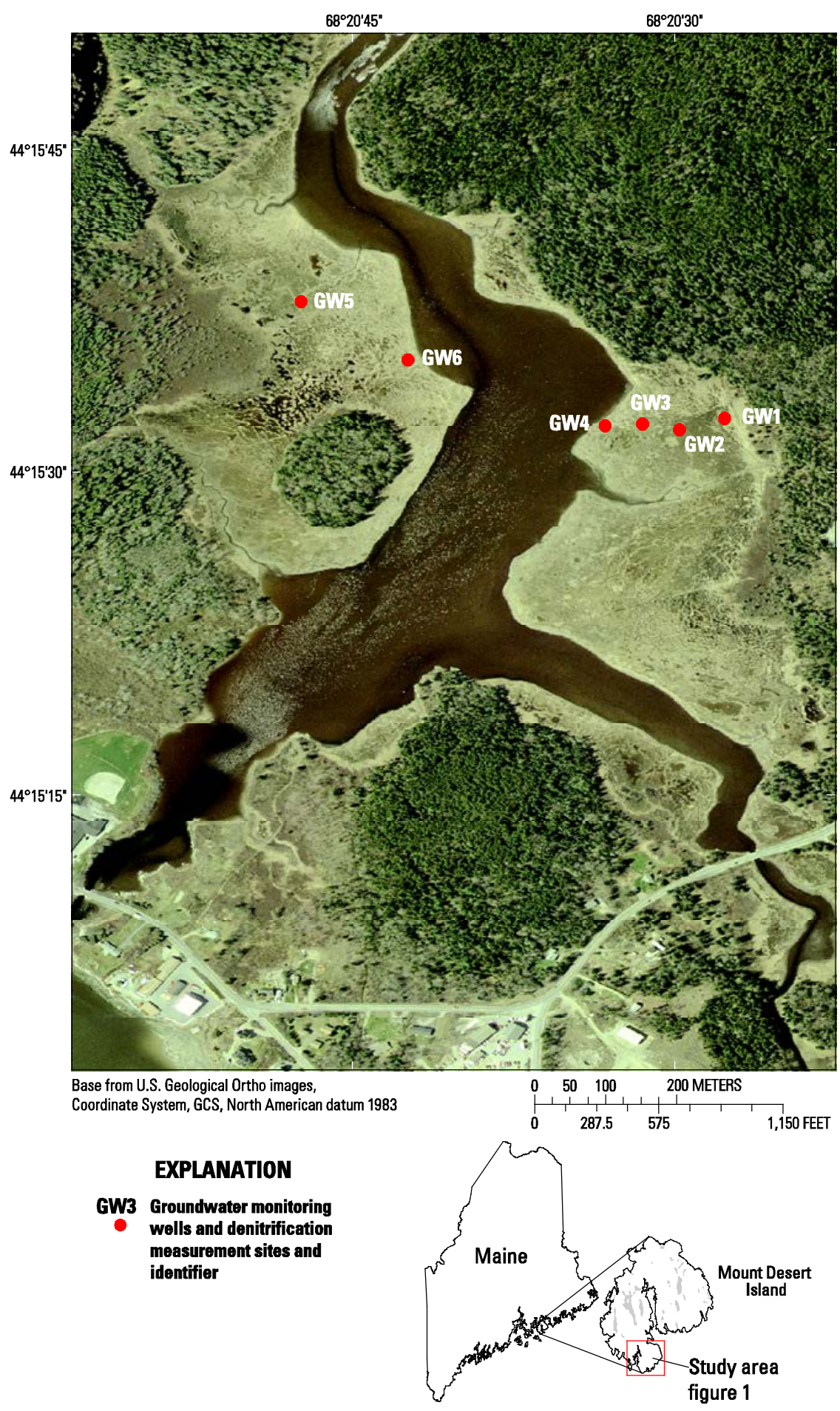

Figure 5. Aerial photograph showing the locations of denitrification measurement sites and groundwater sampling wells in Bass Harbor Marsh watershed, Mount Desert Island, Maine. 
Table 1. Dates of field (in situ) denitrification rate measurements, locations of measurements and treatments applied on those measurement dates.

[NEC, Northeast Creek watershed, GW, groundwater, locations 1 through 6 in each watershed, BHM, Bass Harbor Marsh; $\mathrm{g} \mathrm{n} \mathrm{m}^{-2}$, grams nitrogen per square meter; g glucose $\mathrm{m}^{-2}$, grams glucose per square meter]

\begin{tabular}{|c|c|c|c|c|c|c|c|}
\hline Date & Start & Location & Ambient $^{1}$ & 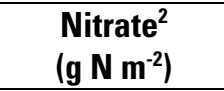 & Acetylene & $\begin{array}{c}\text { Glucose }^{2} \\
\left.\text { (g glucose } \mathrm{m}^{-2}\right)\end{array}$ & $\begin{array}{c}\text { Nitrate + } \\
\text { glucose }\end{array}$ \\
\hline \multirow[t]{2}{*}{ May 2008} & $5 / 29$ & NEC GW1-2 & $\mathrm{X}$ & & & & \\
\hline & $5 / 30$ & NEC GW3-4 & $\mathrm{X}$ & & & & \\
\hline \multirow[t]{3}{*}{ June 2008} & $6 / 10$ & NEC GW1-3 & $\mathrm{X}$ & & $\mathrm{X}$ & & \\
\hline & $6 / 11$ & NEC GW4,6 & $X$ & & & & \\
\hline & $6 / 12$ & NEC GW5 & $\mathrm{X}$ & & & & \\
\hline \multirow[t]{10}{*}{ July 2008} & $7 / 15$ & NEC GW1, GW3 & $\mathrm{X}$ & & & & \\
\hline & $7 / 16$ & NEC GW1, GW3 & & 1.1 & & & \\
\hline & $7 / 16$ & NEC GW4 & $\mathrm{X}$ & & & & \\
\hline & $7 / 17$ & NEC GW2 FC1-3 & $\mathrm{X}$ & & & & \\
\hline & $7 / 17$ & NEC GW2 FC4-6 & $\mathrm{X}$ & 1.1 & & & \\
\hline & $7 / 17$ & NEC GW4 FC4-6 & & 1.1 & & & \\
\hline & $7 / 17$ & NEC GW5 FC1-3 & $\mathrm{X}$ & & & & \\
\hline & $7 / 17$ & NEC GW5 FC5-6 & & 1.1 & & & \\
\hline & $7 / 18$ & NEC GW6 FC1-4 & $\mathrm{X}$ & & & & \\
\hline & $7 / 18$ & NEC GW6 FC5-6 & & 1.1 & & & \\
\hline \multirow[t]{2}{*}{ Aug. 2008} & $8 / 13$ & NEC GW4, GW2 & $\mathrm{X}$ & 1.1 & $\mathrm{X}$ & & \\
\hline & $8 / 14$ & NEC GW4 & & 11 & $\mathrm{X}$ & & \\
\hline \multirow[t]{6}{*}{ Sept 2008} & $9 / 10$ & BHM GW3 & $\mathrm{X}$ & & & & \\
\hline & $9 / 11$ & BHM GW3 & & $5.5,11,16.5,22$ & & & \\
\hline & $9 / 12$ & BHM GW3,GW2 & & 5.5 & $\mathrm{X}$ & & \\
\hline & $9 / 15$ & BHM GW1 & & 5.5 & $\mathrm{X}$ & & \\
\hline & $9 / 15$ & BHM GW4 & & 5.5 & $\mathrm{X}$ & & \\
\hline & $9 / 16$ & BHM GW5 & & 3.3 & & & \\
\hline Oct 2008 & $10 / 30$ & BHM GW6 & & $\begin{array}{l}22,55,110 \\
220\end{array}$ & $\mathrm{X}$ & & \\
\hline \multirow[t]{3}{*}{ June 2009} & $6 / 15$ & BHM GW1-6 & $\mathrm{X}$ & & & & \\
\hline & $6 / 16$ & BHM GW3 & & $\begin{array}{c}1.1,5.5,11,22 \\
55,110\end{array}$ & & 213 & $\mathrm{X}$ \\
\hline & $6 / 17$ & BHM GW2 & & $\begin{array}{c}1.1,5.5,11,22 \\
55,110\end{array}$ & & 213 & $X$ \\
\hline
\end{tabular}


Table 1. Dates of field (in situ) denitrification rate measurements, locations of measurements and treatments applied on those measurement dates.-Continued

[NEC, Northeast Creek watershed, GW, groundwater, locations 1 through 6 in each watershed, BHM, Bass Harbor Marsh; $\mathrm{g} \mathrm{n} \mathrm{m}^{-2}$, grams nitrogen per square meter; g glucose $\mathrm{m}^{-2}$, grams glucose per square meter]

\begin{tabular}{|c|c|c|c|c|c|c|c|}
\hline Date & Start & Location & Ambient ${ }^{1}$ & 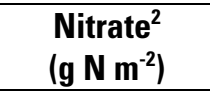 & Acetylene & $\begin{array}{c}\text { Glucose }^{2} \\
\left.\text { (g glucose } \mathrm{m}^{-2}\right)\end{array}$ & $\begin{array}{c}\text { Nitrate + } \\
\text { glucose }\end{array}$ \\
\hline \multirow[t]{4}{*}{ July 2009} & $7 / 13$ & BHM GW1-6 & $\mathrm{X}$ & & & & \\
\hline & $7 / 14$ & BHM GW4 & & $\begin{array}{c}1.1,5.5,11,22 \\
55,110\end{array}$ & & 213 & $\mathrm{X}$ \\
\hline & $7 / 15$ & BHM GW6 & & $\begin{array}{c}1.1,5.5,11,22 \\
55,110\end{array}$ & & 213 & $\mathrm{X}$ \\
\hline & $7 / 16$ & NEC GW1-6 & $\mathrm{X}$ & & & 213 & \\
\hline \multirow[t]{2}{*}{ Aug 2009} & $8 / 25$ & BHM GW1-6 & $\mathrm{X}$ & & & 213 & \\
\hline & $8 / 26$ & BHM GW5 & $\mathrm{X}$ & $\begin{array}{c}1.1,5.5,11,22 \\
44\end{array}$ & & 213 & $\mathrm{X}$ \\
\hline \multirow[t]{2}{*}{ Sep 2009} & $9 / 21$ & NEC GW1-6 & $\mathrm{X}$ & & & 213 & \\
\hline & $9 / 22$ & NEC GW4 & $\mathrm{X}$ & $\begin{array}{c}1.1,5.5,11,22 \\
44\end{array}$ & & 213 & $\mathrm{X}$ \\
\hline
\end{tabular}

${ }^{1} \mathrm{An}$ " $\mathrm{X}$ " indicates that measurements on this date included ambient (no treatment additions) denitrification rate measurements, or, in the case of acetylene an " $\mathrm{X}$ " indicates that measurements on this date included the addition of acetylene.

${ }^{2}$ Nitrate and glucose were added in one liter of solution through the top of the chamber after the chambers were installed in the marsh surface immediately prior to sealing the chamber and beginning the incubation. 


\section{Laboratory Denitrification Methods}

During denitrification both $\mathrm{N}_{2} \mathrm{O}$ and $\mathrm{N}_{2}$ are produced, but $\mathrm{N}_{2}$ is usually the primary byproduct (Meding et al., 2001). The $\mathrm{N}_{2}$-to- $\mathrm{N}_{2} \mathrm{O}$ ratio can be quite variable and dependent upon landscape position (Meding et al., 2001), sediment properties, and availability of nitrate (for example Weier, 1993; Parton and others, 1996). To ensure that future studies could determine the site-specific $\mathrm{N}_{2}$-to- $\mathrm{N}_{2} \mathrm{O}$ ratios, we conducted classical laboratory acetylene inhibition laboratory denitrification assays (Oremland and others, 1984; Duff and others, 1996) on sediment samples collected from each field measurement location. Marsh soil was collected using a hand auger to a depth of 1.25 meter and the material was stored at $4{ }^{\circ} \mathrm{C}$ until use. Large root fragments were removed and the soil material was ground up using a hand-operated meat grinder to facilitate mixing and to allow subsequent subsampling of representative fractions of the original sample. Soils were stored chilled at $4{ }^{\circ} \mathrm{C}$ until use. Approximately 20 grams (g) of fresh soil was weighed into each 133.88 cubic centimeters $\left(\mathrm{cm}^{3}\right)$ glass flask. Groundwater was also obtained at NEC and BHM using a peristaltic pump to pump from shallow piezometers for use in the lab incubations. This groundwater was stored chilled at $4{ }^{\circ} \mathrm{C}$ until use. The groundwater from each location was used to make up solutions containing various concentrations of nitrate on the same day that these treatments were used in the laboratory incubation experiments. Twenty milliliter $(\mathrm{mL})$ of each appropriate solution were added to each flask and then the flasks were sealed. These 20 -mL nitrate additions of 5, 10, 50, 75, 100, 200, 500, and $1,000 \mathrm{mM} \mathrm{NO}_{3}$ were equivalent to nitrogen addition rates of $0.01,0.14,0.7,1.05,1.4,3.5,7$, 14 milligrams of nitrogen per gram $\left(\mathrm{mg} \mathrm{N} \mathrm{g}^{-1}\right)$ fresh soil in the incubation flask (respectively). Deionized water was used to make a stock solution of 1 molar $(\mathrm{M})$ glucose. Syringes were used to add $0.4 \mathrm{~mL}$ of the $1 \mathrm{M}$ glucose solution to each flask that received the glucose treatment for a final glucose concentration of $19.6 \mathrm{mM}$ glucose in the solution added to the fresh marsh soil (equivalent to 3.6 milligrams of glucose per gram ( $\left.\mathrm{mg}_{\text {glucose }} \mathrm{g}^{-1}\right)$ fresh soil fresh soil in the incubation flask). The screw cap flask lids were Teflon lined and were equipped with a rubber septum to provide for syringe additions of glucose, sparging ultra high purity (UHP) He, addition of acetylene, or sampling using syringes.

After sealing, all flasks were sparged with UHP for 20 minutes. For those treatments that received acetylene, $14 \mathrm{~cm}^{3}$ of UHP He was first removed by syringe and then $14 \mathrm{~cm}^{3}$ of acetylene was added to achieve a final headspace concentration of approximately 15 percent acetylene (technical grade, 99.5 percent purity, obtained from Maine Oxy) by volume. All flasks were then placed on a mechanical shaker and shaken for 5 minutes. After this initial equilibration 4- $\mathrm{cm}^{3}$ gas samples were withdrawn from each flask and transferred to 3-mL vacutainers to determine $\mathrm{N}_{2} \mathrm{O}$ concentration at time zero $\left(\mathrm{T}_{0}\right)$. Two gas bags were prepared; one contained UHP He and the other contained 15 percent acetylene (by volume) in UHP He. Four $\mathrm{cm}^{3}$ of "make up" gas from the appropriate bag were added to all flasks after collecting $\mathrm{T}_{0}$ samples to restore the original headspace gas volume and pressure. After the addition of the appropriate "make up" gas for each treatment, the flasks were shaken continuously until the subsequent gas sample collections (e.g. $\mathrm{T}_{1}, \mathrm{~T}_{2}, \mathrm{~T}_{3}$, or $\mathrm{T}_{4}$ ). During each subsequent sampling, $4 \mathrm{~cm}^{3}$ of gas was collected from the headspace by syringe and transferred to a $3-\mathrm{mL}$ vacutainer and $4 \mathrm{~mL}$ of make up gas was added back to each flask. The gas samples in vacutainers (glass vials) sealed with Teflon lined butyl rubber stoppers were shipped by Federal Express in cardboard containers to a USGS laboratory specializing in gas analysis (Menlo Park, Calif.) for determination of $\mathrm{N}_{2} \mathrm{O}$ concentration. 
In most laboratory assays where nitrate was added, two, and sometimes three replicate chambers were used to determine average $\mathrm{N}_{2} 0$ production rates in laboratory assays. None of the laboratory assays included three replicate samples under ambient conditions. For all laboratory assays with three replicate samples, we calculated the standard error as a percent of the mean value (SE percent) recorded in the data tables. For the first time period $\left(T_{0}\right.$ to $\left.T_{1}\right) 90$ percent of the nitrate addition treatments had SE percent in the range of 2 to 97 percent and the median SE percent was 17 percent. Median SE percent decreased during the second time period $\left(T_{1}\right.$ to $\left.T_{2}\right)$ to 12 percent in these nitrate addition trials.

Subsamples of fresh, ground, and homogenized marsh soils were analyzed at the Maine Water Science Center Laboratory to determine the water fraction and the organic matter (OM) fraction. Fresh soil samples were weighed and then oven dried at $105^{\circ} \mathrm{C}$ until they reached a constant weight and then they were reweighed to gravimetrically determine the water fraction ( $\mathrm{g}$ water per $\mathrm{g}$ oven dry soil). These samples were then ashed in a muffle furnace at $500^{\circ} \mathrm{C}$ until they reached a constant weight and then they were reweighed to gravimetrically determine the OM content (g OM per g oven dry soil) (Davies, 1974).

\section{Laboratory Methods and Computation of $\mathrm{N}_{2} \mathrm{O}$ Release Rate}

Gas samples were analyzed by Ni-63 electron capture detection gas chromatography (GC-ECD) using standard methods (Oremland and others, 1984; Duff, 1996, Aelion and Shaw, 2000). The laboratory reported the $\mathrm{N}_{2} \mathrm{O}$ concentrations from the vacutainers (headspace at each sampling time) in units of nanomoles per milliliter (nmoles $\left.\mathrm{mL}^{-1}\right) \mathrm{N}_{2} \mathrm{O}$. The gas chromatograph is typically calibrated with Scott mini mix calibration standards twice during each run with a minimum of five concentrations that bracket the samples. Single point calibrations ( 0.0446 nmoles $\mathrm{N}_{2} 0$ per injection) are run approximately every 20 samples. The standard curves typically span from 0.00446 to 2.23 nmoles $\mathrm{N}_{2} \mathrm{O}$ per injection depending on the sample range with $\mathrm{r}^{2} \mathrm{~s}>0.99$. The relative standard deviation of repeated standards typically averages 3.8 percent with a standard deviation of $+/-1.9$ percent over the standard range. Laboratory air analyses are also run $\left(0.00156\right.$ nmoles $\left.\mathrm{N}_{2} \mathrm{O}\right)$. The relative standard deviation is significantly higher (25.6 precent) since laboratory air concentrations can not be controlled. During all laboratory sample analysis runs, $\mathrm{N}_{2} \mathrm{O}$-free calibration gas is substituted for $\mathrm{N}_{2} \mathrm{O}$ standards or environmental samples to determine a baseline reading.

In situ $\mathrm{N}_{2} \mathrm{O}$ release rates were determined as nmoles $\mathrm{m}^{-2} \mathrm{hr}^{-1}$ using the chamber headspace volume, the initial and subsequent headspace concentrations, the area of the marsh surface covered by the chamber $\left(\mathrm{m}^{-2}\right)$, and the duration of the incubation (hour (hr)):

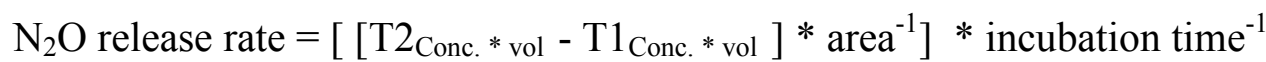

The $\mathrm{N}_{2} \mathrm{O}$ release rates reported herein did not account for the $\mathrm{N}_{2} \mathrm{O}$ produced during the lab incubations that was retained in the liquid phase. About 17 percent of the total $\mathrm{N}_{2} \mathrm{O}$ produced was retained in the liquid phase based on a simple Henry's Law calculation for incubations conducted at $25^{\circ} \mathrm{C}$ using a Bunsen absorption coefficient of 0.544 as described in Tiedge (1983).

\section{Water Quality Data Collection Methods}

Water quality samples were collected from tributaries that flow into the NEC and BHM estuaries (figs. 2 and 3; table 2) on an approximately monthly schedule during the 2008 and 2009 growing seasons. These samples were analyzed for the constituents shown in table 3. Samples 
were collected from shallow groundwater in NEC and BHM marsh soils at the locations where in situ denitrification measurements were made during the 2008 and 2009 growing seasons (figs. 4 and 5). Various quality-assurance samples were also collected to determine bias and precision associated with the sample data.

\section{Field Methods}

For the surface water quality sampling sites on the NEC and BHM tributaries, a peristaltic pump was used to pump water directly from a fast flowing section of the tributary and through a cartridge filter ( 0.45 micron polyethersulfone membrane filter) and into $125-\mathrm{mL}$ amber polyethylene bottles at each measuring station. For the groundwater samples, all samples were collected by pumping water from shallow piezometers that were installed in the NEC and BHM marsh soils at the locations where denitrification measurements were made. The piezometers were commercial PVC, 5-cm diameter, 1-meter length, and screened over their entire length, except within $15-\mathrm{cm}$ of each end. The screen size was $0.0254 \mathrm{~cm}$ and the bottoms of the piezometers were equipped with a conical $5-\mathrm{cm}$ well point. For installation, holes were augured with a hand auger using a $3.75-\mathrm{cm}$ diameter bit to ensure a tight seal between the piezometers and the surrounding marsh soil. Piezometers were installed with 10-cm of unscreened pipe above ground surface. Caps were installed to prevent precipitation from entering the piezometers. Samples were pumped with a peristaltic pump or a vacuum pump into $250-\mathrm{mL}$ polyethylene bottles. All polyethylene bottles were prewashed and rinsed profusely prior to sample collection. Groundwater samples were filtered on site with syringe cartridge filters, or were filtered in a laboratory within 6 hours using a peristaltic pump and a cartridge filter or a syringe and a cartridge filter. All filters were 0.45 micron pore size and all samples were filtered into $125-\mathrm{mL}$ amber polyethylene bottles and chilled immediately.

All amber polyethylene sample bottles were acid washed and rinsed 3 times with filtered sample prior to sample collection. Samples were chilled on ice from the time of collection until received at the Maine Water Science Center in Augusta, Maine within 36 to 48 hours of collection. All samples were frozen in Augusta and stored frozen before overnight shipment to the Woods Hole Oceanographic Institute, Nutrient Analytical Facility (WHOI) for analysis. All samples were maintained frozen at WHOI until they were analyzed. All samples were analyzed for all constituents at the WHOI Nutrient Analytical Facility.

Field values for specific conductance and water temperature were measured at the time of sample collection using an Orion Model 122 meter or a YSI EC 300 meter (Wilde, variously dated). The meter was calibrated prior to each use using standard solutions for specific conductance. For surface water measurements the Orion or YSI probe was placed directly in a fast flowing section of the stream and allowed to equilibrate before recording the value. For groundwater measurements samples were pumped into a beaker (if the peristaltic pump was used) and the Orion or EC 300 probe was placed into the beaker while water was pumped in and allowed to equilibrate before readings were recorded. If the hand vacuum pump were used, water was first pumped into a vacuum flask and was then poured into a beaker and the Orion or YSI probe was placed into the beaker and readings were recorded within 30 seconds. Dissolved oxygen was determined using a Chemetrics field test kit employing the indigo carmine colorimetric method (ASTM D 887-87) (Gilbert and others, 1982). 
Table 2. Surface water and groundwater water-quality monitoring stations in Northeast Creek and Bass Harbor Marsh watersheds sampled in 2008 and 2009.

$\left[\mathrm{mi}^{2}\right.$, square miles; Dr., Drive, nr, near; ME, Maine, latitude and longitude determined with Global Positioning System (GPS) (+/- 2 to 5 meters); NEC, Northeast Creek watershed, GW, groundwater, locations 1 through 6 in each watershed, BHM (Bass Harbor Marsh watershed) Str., stream; Br. Brook]

\begin{tabular}{|c|c|c|c|c|c|}
\hline Station Name & $\begin{array}{c}\text { USGS } \\
\text { station } \\
\text { number }\end{array}$ & Latitude & Longitude & $\begin{array}{c}\text { Drainage } \\
\text { area in } \mathrm{mi}^{2}\end{array}$ & $\begin{array}{c}\text { Number of } \\
\text { samples }\end{array}$ \\
\hline \multicolumn{6}{|c|}{ Surface water sites } \\
\hline Aunt Betsey's Brook near Bar Harbor, ME & 01022815 & 442422.0 & 681910.0 & 0.63 & 11 \\
\hline French Hill Brook near Bar Harbor, ME & 01022817 & 442423.0 & 681844.0 & 0.56 & 11 \\
\hline Old Mill Brook at Old Norway Dr. nr Bar Harbor, ME & 01022800 & 442355.0 & 681714.0 & 1.55 & 12 \\
\hline Marshall Brook near Southwest Harbor, ME & 01022890 & 441629.0 & 682105.0 & 1.97 & 7 \\
\hline Lurvey Brook near Southwest Harbor, ME & 01022892 & 441644.0 & 682128.0 & 0.105 & 6 \\
\hline Heath Brook near Tremont, ME & 01022895 & 441640.0 & 682205.0 & 0.91 & 8 \\
\hline Buttermilk Brook near Southwest Harbor, ME & $\mathrm{N} / \mathrm{A}$ & 441559.6 & 682038.5 & & 1 \\
\hline Stony Brook below Hamilton Pond nr Bar Harbor, ME & 01022810 & 442528.0 & 681729.0 & 2.66 & 1 \\
\hline Adams Brook near Southwest Harbor, ME & N/A & 441452.3 & 682022.4 & & 1 \\
\hline Adams Brook near Southwest Harbor, ME & N/A & 441435.3 & 681953.0 & & 1 \\
\hline Adams Brook near Southwest Harbor, ME & N/A & 441437.4 & 681958.3 & & 1 \\
\hline Adams Brook near Southwest Harbor, ME & $\mathrm{N} / \mathrm{A}$ & 441445.0 & 682009.2 & & 1 \\
\hline Aunt Betsey's Estuary nr Bar Harbor, ME & $\mathrm{N} / \mathrm{A}$ & 442438.7 & 681845.8 & $\mathrm{~N} / \mathrm{A}$ & 1 \\
\hline Bass Harbor Marsh Estuary, nr SW Harbor, ME ${ }^{2}$ & N/A & 441535.2 & 682042.4 & N/A & 1 \\
\hline Bass Harbor Marsh Estuary, nr SW Harbor, $\mathrm{ME}^{3}$ & N/A & 441535.2 & 682042.4 & N/A & 1 \\
\hline Intermittent Str. draining to Aunt Betsey's Br. nr GW2 & $\mathrm{N} / \mathrm{A}$ & 442440.0 & 681832.0 & N/A & 1 \\
\hline
\end{tabular}




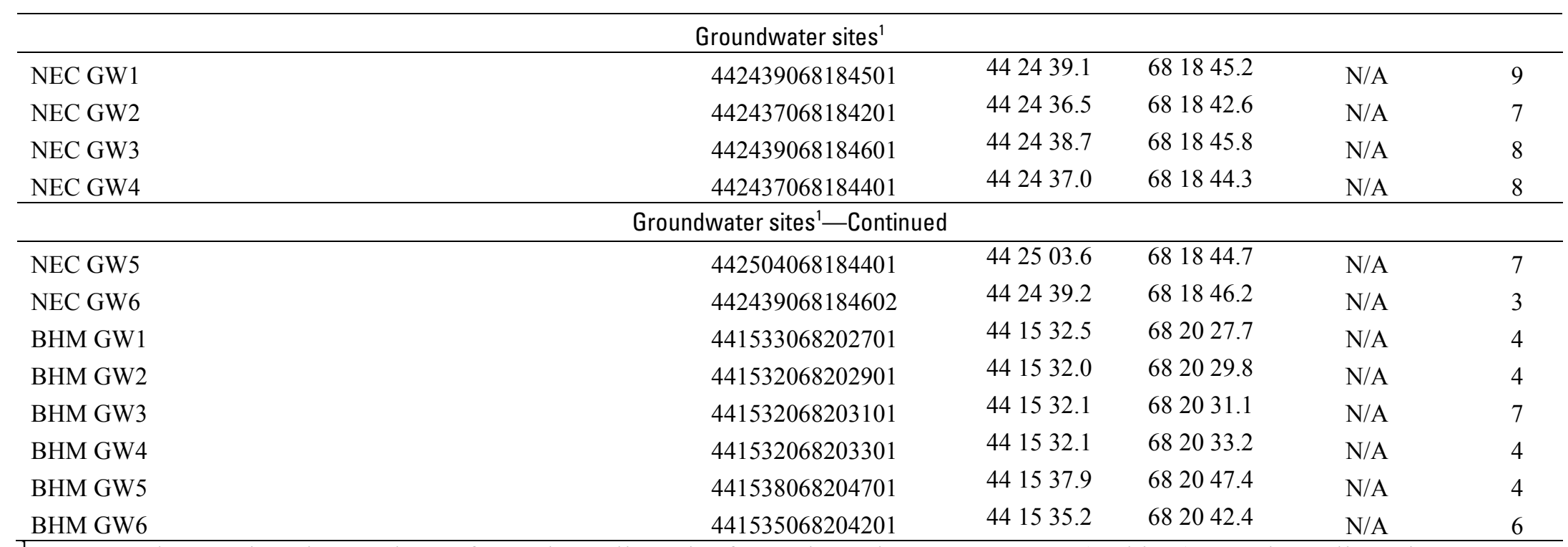

${ }^{\mathrm{T}}$ For groundwater sites the numbers of samples collected refers only to the pre-treatment (ambient) samples collected

${ }^{2}$ sampled collected at water surface

${ }^{3}$ sample collected $20 \mathrm{~cm}$ below water surface 
Table 3. Constituent name, U.S. Geological Survey National Water Information System parameter codes and method codes, and minimum reporting limits for temperature, specific conductance, dissolved oxygen, and nutrients.

$\left[{ }^{\circ} \mathrm{C}\right.$, degrees Celsius;, na, not applicable; $\mu \mathrm{s} / \mathrm{cm}$, micro Siemens per centimeter; $\mathrm{mg} / \mathrm{L}$, milligrams per liter; $\mathrm{N}$, nitrogen; $\mathrm{SiO}_{2}$, silica, dissolsved; $\mathrm{P}$, phosphorus;]

\begin{tabular}{clcc}
\hline Parameter code & \multicolumn{1}{c}{ Constituent name } & Method code & $\begin{array}{c}\text { Minimum or } \\
\text { laboratory } \\
\text { reporting limit }\end{array}$ \\
\hline 00010 & Temperature, water $\left({ }^{\circ} \mathrm{C}\right)$ & na & $0.01{ }^{\circ} \mathrm{C}$ \\
00094 & Specific conductance, field $\left(\mu \mathrm{s} / \mathrm{cm}\right.$ at $\left.25{ }^{\circ} \mathrm{C}\right)$ & na & $1.0 \mu \mathrm{s} / \mathrm{cm}$ \\
00300 & Oxygen, dissolved $(\mathrm{mg} / \mathrm{L})$ & na & $0.1 \mathrm{mg} / \mathrm{L}$ \\
00608 & Ammonium $(\mathrm{mg} / \mathrm{L}$ as N) & 00623 & $0.01 \mathrm{mg} / \mathrm{L}$ \\
00955 & Silica, dissolved $\left(\mathrm{mg} / \mathrm{L}\right.$ as $\left.\mathrm{SiO}_{2}\right)$ & $\mathrm{CL} 151$ & $0.5 \mathrm{mg} / \mathrm{L}$ \\
00671 & Phosphorus, orthophosphate, dissolved $(\mathrm{mg} / \mathrm{L}$ as $\mathrm{P})$ & 00048 & $0.006 \mathrm{mg} / \mathrm{L}$ \\
00618 & Nitrate + Nitrite $(\mathrm{mg} / \mathrm{L}$ as aN) & CL050 & $0.10 \mathrm{mg} / \mathrm{L}$ \\
62854 & Nitrogen, total, dissolved $(\mathrm{mg} / \mathrm{L}$ and $\mathrm{N})$ & CL063 & $0.01 \mathrm{mg} / \mathrm{L}$ \\
\hline
\end{tabular}

${ }^{1}$ For groundwater sites the numbers of samples collected refers only to the pre-treatment (ambient) samples collected.

${ }^{2}$ Sampled collected at water surface.

${ }^{3}$ Sample collected $20 \mathrm{~cm}$ below water surface. 


\section{Laboratory Methods}

Ammonia was analyzed colorimetrically by the indophenol method Lachat QuickChem Method 31-107-060-1-B (Scheiner, 1976; method 4500-NH3-F, p. 4.108-4.109, American Public Health Association, 1998). Silicate was analyzed colorimetrically by using Lachat QuickChem Method 31-114-27-1-C (method 4500-SiO2-F, p.4-160 and 4-161, American Public Health Association, 1998). Phosphate was analyzed colorimetrically by Lachat QuickChem Method 31-115-01-1-H (Murphy and Riley, 1962; method 4500-P-E, p.4-146 and 4-147, American Public Health Association, 1998). Nitrate plus nitrite were analyzed colorimetrically by using Lachat QuickChem Method 31-107-04-1-E (Wood and others 1967; method 4500- $\mathrm{NO}_{3}-\mathrm{F}$, p. 4-118 and 4-119, American Public Health Association, 1998). The concentration of nitrite in these waters is expected to be below detection and therefore throughout the report this analysis is referred to as nitrate. Total dissolved nitrogen was analyzed colorimetrically following alkaline persulfate digestion (D'Elia and others, 1977; method 4500-Norg, p.4-102 and 4-103, American Public Health Association, 1998).

The reliability of the chemical data was ensured by the preparation and analysis of several types of quality-control samples. These quality-control samples include 1 field blank and 10 replicate samples under ambient conditions and, and 3 replicate samples of groundwater following a nitrate addition treatment. Four replicate samples were also sent to the USGS National Water Quality Laboratory (NWQL), in Denver, Colorado, where they were analyzed for nitrate plus nitrate, ammonia, and total dissolved nitrogen. Additionally, reasonable range checks were performed by comparing laboratory-determined chemical data for the sampled tributaries with results reported for these tributaries that were sampled during previous studies.

A field blank is used to test for positive bias that can result from contamination during any stage of sample collection, processing, or analysis. A field blank was prepared from deionized water that was produced by a laboratory-grade water purification system that uses a sequence of ion exchange resin columns. The resulting purified water has a specific conductance between 1 and 3 microsiemens. One field blank was collected during sampling at base-flow conditions in October 2008. During collection of base-flow samples, the field blank was collected by transferring blank water from the holding bottle to the sample-collection bottle. It was then processed, stored, and shipped to the analytical laboratory in a manner consistent with the collection of other environmental samples.

Replicate samples are samples thought to be identical in composition to the environmental samples. Replicate samples provide a measure of bias and variability for the method of sample collection, sample processing (splitting, filtering, and preservation), and laboratory analysis. Replicate samples were collected from tributaries (Aunt Betseys Brook, Marshall Brook, French Hill Brook, Old Mill Brook, Heath Brook and Adams Brook) during base-flow conditions in September 2008, October 2008, and August 2009. One replicate sample was collected from a groundwater sampling location (NEC GW2) in Fresh Meadow Marsh, Northeast Creek in August 2008. Three replicate samples were collected from a groundwater sampling location (NEC GW4) in Fresh Meadow Marsh, Northeast Creek in August 2008 following the addition of 1 liter of a $50 \mathrm{mM}$ nitrate solution to the marsh surface.

In addition to the quality-assurance samples collected during this project, WHOI and NWQL routinely analyze various quality-control samples, including laboratory reagent blanks, interference check solutions, laboratory control samples, standard reference materials, laboratory reagent spike samples, and laboratory duplicate samples (Furlong and others, 2001; Garbarino and others, 2006; written communication, Paul Henderson, WHOI, 2011). Both laboratories also 
participate in participate in laboratory-intercalibration (blind sample) programs including GEOTRACES [http://www.obs-vlfr.fr/GEOTRACES/index.php/science/intercalibration] to test and track method performance. The WHOI laboratory uses the QUASIMEME project (Quality Assurance of Information for Marine Environmental Monitoring in Europe) standardization protocols (Cofino and Wells, 1994).

\section{Ancillary Data Collection Methods}

Water level was recorded continuously at one site (USGS Station ID No. 442439068184502) in Fresh Meadow Marsh, Northeast Creek (fig. 2) using standard U.S. Geological Survey methods. The well was equipped with a Design Analysis DH21 submersible pressure transducer programmed to record water level and water temperature every fifteen minutes.

Soil temperature was recorded periodically at each of the principle denitrification measurement sites. Soil temperature was determined at a soil depth of $15 \mathrm{~cm}$ below the surface with a glass thermometer.

Daily precipitation data were obtained from the National Park Service (NPS at Acadia National Park). The NPS maintains a National Atmospheric Deposition Program (NADP) monitoring site that uses a Belfort tipping bucket rain gage to record daily precipitation data at McFarland Hill on Mount Desert Island. The NADP program is administered by the Illinois State Water Survey, Champaign, Ill. Data can be accessed from the URL http://nadp.sws.uiuc.edu/.

Tidal data were obtained from National Oceanographic and Atmospheric Administration (NOAA) data files [http://tidesandcurrents.noaa.gov] accessed on 12/20/2009 for Frenchman's Bay, Bar Harbor, Maine on Mount Desert Island. Stream-water discharge records were obtained for Otter Creek near Bar Harbor, Maine (USGS station ID 01022840). Streamwater data was obtained from the USGS National Water Information System (NWIS) [http://waterdata.usgs.gov/me/nwis/uv/?site_no=01022840] accessed on 4/1/2010.

\section{Field Denitrification Data}

In these descriptions of data obtained in field experiments nitrate additions of 1 -L of 0,5 , $15,25,50,75,100,250,500$, and 1,000 $\mathrm{mM} \mathrm{NO} 3$ were equivalent to nitrogen addition rates of $0,1.1,3.3,5.5,11,17,22,55,110$, and $221 \mathrm{~N} \mathrm{~m}-2$ respectively. Field denitrification measurements under ambient conditions (no treatments) were conducted in NEC watershed during June 10 through June 12, 2008 at six locations, and at two of those locations (GW1 and GW2) acetylene was added as a treatment (table 4). Field denitrification measurements were conducted in NEC watershed during July 15 through July 19, 2008 at six locations and included ambient and $5 \mathrm{mM}$ nitrate additions to all locations (table 5). Field denitrification measurements were conducted in NEC watershed during August 13 through August 15, 2008 at two locations (GW2 and GW4) and included ambient, and 5, and $50 \mathrm{mM}$ nitrate additions to both locations (table 6). Field denitrification measurements were conducted in BHM watershed during September 13 through September 16, 2008 at six locations. During these September 2008 measurements, ambient, and 25, 50, 75, and $100 \mathrm{mM}$ nitrate additions were conducted on GW3 (table 7). In addition, during these September 2008 measurements, sites GW1, GW2, GW3 and GW4 received $25 \mathrm{mM}$ nitrate treatments and $25 \mathrm{mM}$ nitrate plus acetylene treatments, and GW5 and GW6 received $15 \mathrm{mM}$ nitrate treatments (table 7). Field denitrification measurements were 
conducted in BHM watershed during October 30 through October 31, 2008 at one location (GW6). During this October 2008 measurement, treatments included 100, 250, 500, and $1000 \mathrm{mM}$ nitrate with and without acetylene (table 8).

Field denitrification measurements under ambient conditions were conducted in BHM watershed during June 15 through June 16, 2009 at six locations (table 9). Field denitrification measurements were conducted in BHM watershed during June 16 through June 17, 2009 at the GW3 location that included 5, 25, 50, 100, 250, and $500 \mathrm{mM}$ nitrate with and without $75 \mathrm{mM}$ glucose and one treatment with $75 \mathrm{mM}$ glucose only (table 9). Field denitrification measurements were conducted in BHM watershed during June 17 through June 18, 2009 at the GW2 location that included 5, 25, 50, 250, and $500 \mathrm{mM}$ nitrate with and without $75 \mathrm{mM}$ glucose and one treatment with $75 \mathrm{mM}$ glucose only (table 9). Field denitrification measurements under ambient conditions were conducted in BHM watershed on July 13, 2009 at six locations (table 10). Field denitrification measurements were conducted in BHM watershed during July 14 through July 16, 2009 at the GW4 and GW6 locations that included 5, 25, 50, 100, 250, and $500 \mathrm{mM}$ nitrate with and without $75 \mathrm{mM}$ glucose (table 10). Field denitrification measurements under ambient conditions and with $75 \mathrm{mM}$ glucose additions were conducted in NEC watershed on July 16, 2009 at six locations (table 10). Field denitrification measurements under ambient conditions and with $75 \mathrm{mM}$ glucose additions were conducted in BHM watershed during August 25 through August 26, 2009 at six locations (table 11). Field denitrification measurements were conducted in BHM watershed during August 26 through August 27, 2009 at the GW5 location that included ambient conditions; $75 \mathrm{mM}$ glucose; and 5, 25, 50, 100, and $200 \mathrm{mM}$ nitrate with and without $75 \mathrm{mM}$ glucose (table 11). Field denitrification measurements under ambient conditions and with $75 \mathrm{mM}$ glucose additions were conducted in NEC watershed during September 21 through September 22, 2009 at six locations (table 12). Field denitrification measurements were conducted in NEC watershed during September 22 through September 23, 2009 at the GW4 location that included ambient; $75 \mathrm{mM}$ glucose; and 5, 25, 50, 100, and $200 \mathrm{mM}$ nitrate with and without $75 \mathrm{mM}$ glucose (table 12).

\section{Laboratory Denitrification Data}

In these descriptions of data obtained in laboratory experiments nitrate additions of $20-\mathrm{mL}$ of $5,10,50,75,100,200,500$, and 1,000 $\mathrm{mM} \mathrm{NO} 3$ were equivalent to nitrogen addition rates of $0.01,0.14,0.7,1.05,1.4,3.5,7$, and $14 \mathrm{mg} \mathrm{N} \mathrm{mg} \mathrm{N} \mathrm{g-1} \mathrm{fresh} \mathrm{soil} \mathrm{respectively.} \mathrm{The}$ gravimetric analysis of fresh soil samples to determine the dry weight and organic matter fraction for the denitrification measurement sites in NEC and BHM are reported in table 13. On May 5, 2009, soils from NEC (GW1 and GW2) and BHM (GW1) were incubated with 0 and $50 \mathrm{mM} \mathrm{NO}_{3}$ with and without acetylene and denitrification rates were determined (table 14). On May 7, 2009, soils from NEC (GW2, GW3, GW4, and GW5) were incubated with $50 \mathrm{mM} \mathrm{NO}_{3}$ with and without acetylene and denitrification rates were determined (table 15). On May 13, 2009, soils from NEC (GW6) and BHM (GW2, GW3, and GW4) were incubated with $50 \mathrm{mM} \mathrm{NO}_{3}$ with and without acetylene and denitrification rates were determined (table 16). On May 15, 2009, soils from BHM (GW5 and GW6) were incubated with $50 \mathrm{mM} \mathrm{NO}_{3}$ with and without acetylene and denitrification rates were determined (table 17). On May 20, 2009, soils from NEC (GW4) were incubated with $0,5,10,50,75,100,250,500,750$, and $1000 \mathrm{mM} \mathrm{NO}_{3}$ with and without acetylene and with and without glucose and denitrification rates were determined (table 18). On May 22, 2009, soils from NEC (GW2) and BHM (GW2) were incubated with 0,75 , and $500 \mathrm{mM} \mathrm{NO}_{3}$ with and without acetylene and with and without 
glucose and denitrification rates were determined (table 19). On May 27, 2009, soils from NEC (GW5) and BHM (GW3) were incubated with 0,75 , and $500 \mathrm{mM} \mathrm{NO}_{3}$ with and without acetylene and with and without glucose and denitrification rates were determined (table 20). On May 29, 2009, soils from NEC (GW1) and BHM (GW5) were incubated with 0, 75, and $500 \mathrm{mM}$ $\mathrm{NO}_{3}$ with and without acetylene and with and without glucose and denitrification rates were determined (table 21). On June 2, 2009, soils from NEC (GW3) and BHM (GW1) were incubated with 0 and $75 \mathrm{mM} \mathrm{NO}_{3}$ with and without acetylene and with and without glucose and denitrification rates were determined (table 22).

\section{Water-Quality Data}

Water quality samples were collected periodically during May through October in 2008 and 2009 from the sites listed in table 2 . The surface water nutrient water-quality data are reported in table 23 and the field measurements of temperature and specific conductance are reported in table 24. The groundwater nutrient water-quality data for NEC and BHM are reported in tables 25 and 26 and the field measurements of temperature, specific conductance, and dissolved oxygen are reported in table 27.

\section{Quality-Control Samples}

Trace amounts of ammonium, nitrate plus nitrite, phosphate, silicate, and total dissolved nitrogen were detected in the field blank. The concentration for these constituents measured in the field blank was one or more orders of magnitude less that the lowest concentration found in all of the environmental samples, and at least one order of magnitude lower than the minimum reporting limit for each constituent.

Field replicate samples were analyzed by comparing the relative percent differences (RPDs) of the results for each pair of samples where the same analyte was detected in both samples. The RPD was calculated as the absolute difference between replicate analyses divided by the average of the same two values. The RPDs for total dissolved nitrogen and for phosphate varied by 7 percent or less for the 3 replicate samples collected from tributaries that were analyzed in the WHOI laboratory. The RPDs for ammonium and silicate varied by between 3 and 53 percent for the same tributary replicate samples. The RPDs for nitrate plus nitrite for these same tributary replicate samples were higher, varying between 29 percent and 141 percent. We can not explain these higher RPDs for nitrate plus nitrite in these tributary samples, especially since the RPDs for total dissolved nitrogen for these samples varied by only 7 percent or less. Previously published analyses for these streams (Nielsen and Kahl, 2007; Culbertson and others, 2007) and analyses for these streams conducted for the Northeast Temperate Network (NETN) (unpublished data, written communication, Bill Gawley, National Park Service) are consistent with the higher of the two replicate analyses for nitrate plus nitrate. These replicate nitrate plus nitrite concentrations are relatively low and precision is usually lower for lower analyte concentrations.

Four separate samples from tributaries were analyzed in both the WHOI and NWQL laboratories for ammonium, nitrate plus nitrite, and total dissolved nitrogen. It was not possible to calculate RPDs for ammonium and nitrate because the concentrations of these constituents generally were below the minimum reporting limit for the NWQL laboratory. The RPD for total dissolved nitrogen varied between 81 and 138 percent and the NWQL-determined concentrations 
were always higher than those determined by the WHOI laboratory. The WHOI-determined concentrations appear to be more consistent with previously published vales based on the calculated ratios of total dissolved nitrogen to nitrate plus nitrite. The NWQL concentrations result in ratios of total dissolved nitrogen to nitrate plus nitrite that are unprecedentedly high. The RPDs for nitrate plus nitrite determined for the untreated groundwater environmental sample and field replicate (NEC GW2) and among the 3 replicate groundwater samples collected at NEC GW4 following application of the $50 \mathrm{mM}$ nitrate treatment were less than 1 percent.

Samples of gas collected from the free atmosphere above the marsh and from the chamber headspace immediately after placement and sealing on the marsh surface were analyzed for $\mathrm{N}_{2} \mathrm{O}$ and in all cases determined $\mathrm{N}_{2} \mathrm{O}$ concentrations were at least one order of magnitude below the lowest calibration standard indicating only trace amounts of $\mathrm{N}_{2} \mathrm{O}$ were present. In all cases, when $\mathrm{N}_{2} \mathrm{O}$-free calibration gas was substituted for $\mathrm{N}_{2} \mathrm{O}$ standards or environmental samples during laboratory gaschromatographic analysis no $\mathrm{N}_{2} \mathrm{O}$ was detected.

\section{Ancillary Data}

Water level (in feet relative to land surface) for Fresh Meadow Marsh in Northeast Creek from May 2009 through December 2009 is shown in figure 6A. Discharge (cubic feet per second

$\left.\left(\mathrm{ft}^{3} / \mathrm{s}\right)\right)$ at Otter Creek on Mount Desert Island from May 2009 through December 2009 is also shown in figure 6A. Daily precipitation (inches) at McFarland Hill Station, near Bar Harbor, Mount Desert Island, from May 2009 through December 2009 is shown in figure 6B. Soil temperature $\left({ }^{\circ} \mathrm{C}\right)$ recorded at $15 \mathrm{~cm}$ soil depth during denitrification measurements is reported in tables 4 through 12 . 

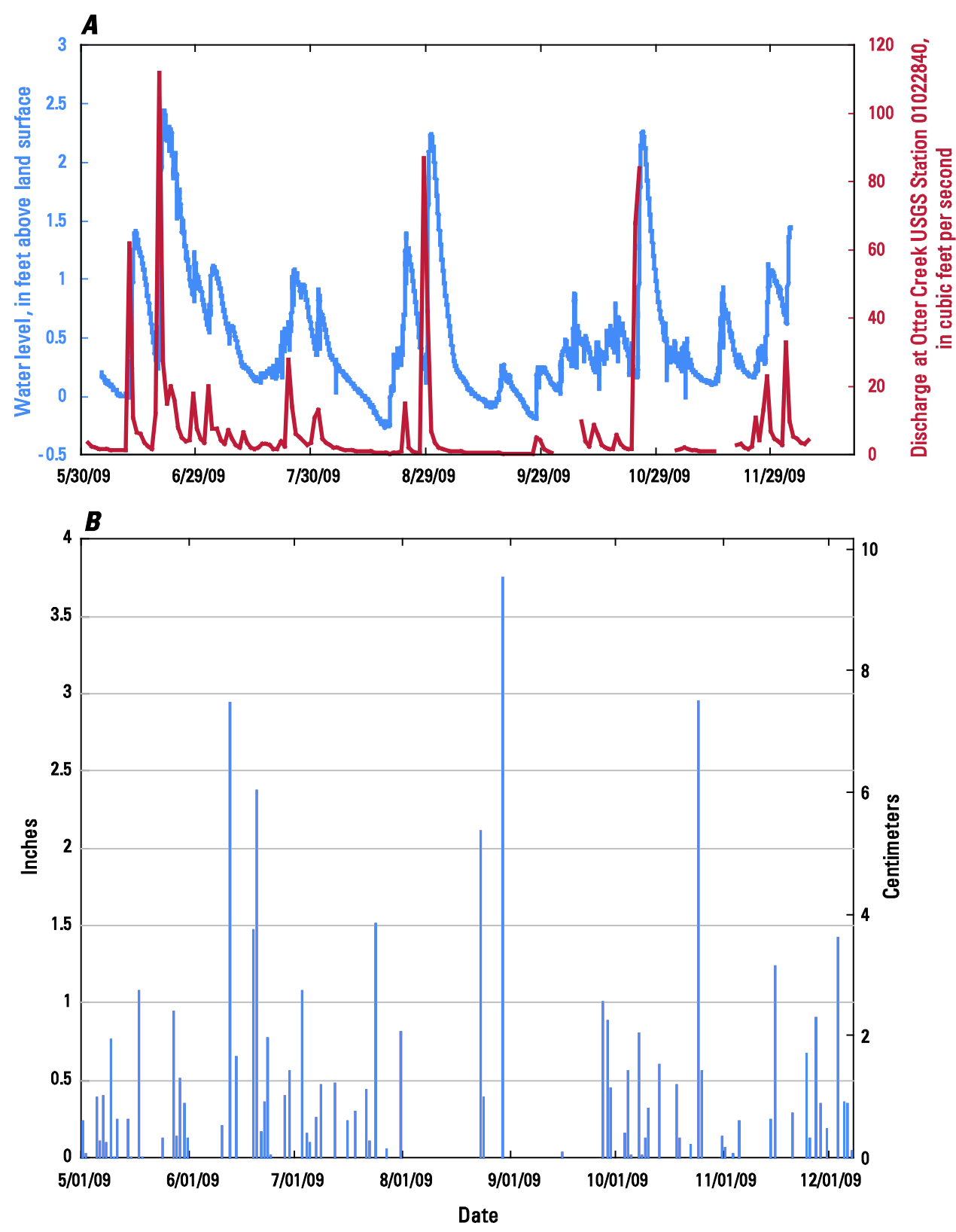

Figure 6. Graphs showing A, Water level in Fresh Meadow Marsh, Northeast Creek watershed, Mount Desert Island, Maine and discharge at Otter Creek USGS station ID 01022840 and $B$, daily precipitation at McFarland Hill Station, near Bar Harbor, Mount Desert Island, Maine. 


\section{References Cited}

Acadia National Park, 2000, Water Resources Management Plan, Kahl,S., Manski, D., Flora, M., and Houtman, N., eds. NPS D-209, April 2000, 102 p.

Aelion, C.M., and Shaw, J.N., 2000, Denitrification in South Carolina (USA) Coastal Plain Aquatic Sediments: Journal of Environmental Quality, v. 29, p. 1696-1702.

American Public Health Association, 1998, Standard methods for the examination of water and wastewater (20th ed.): Washington, D.C., American Public Health Association.

Bricker, S., Clement, C.G., Pirhalla, D.E., Orlando, S.P., and Farrow, D.R.G., 1999, National estuarine eutrophication assessment of nutrient enrichment in the Nations' estuaries, NOAA, Natl. Ocean Serv., Special Projects Office and the Natlional Centers for Coastal Ocean Science, Silver Spring, MD, 71pp.

Burke, D.J., Hamerlynck, E.P., and Hahn, D., 2002, Interactions among plant species and microorganisms in salt marsh sediments: Applied and Environmental Microbiology, v. 68, no. 3 , p. $1,157-1,164$.

Calhoun, A.J.K., Cormier, J.E., Owen, R.B.J., Roman, C.T., and Tiner, R.W.J., 1994, The wetlands of Acadia National Park and vicinity: Maine Agriculture and Forest Experiment Station Miscellaneous Report Publication 721. University of Maine, Orono.

Cloern, J.E., 2001, Our evolving conceptual model of the coastal eutrophication problem: Marine Ecology Progress Series, v. 210, p. 223-253.

Cofino, W.P., and Wells, D.E., 1994, Design and evaluation of the QUASIMEME laboratory performance studies: a test case for robust statistics: Marine Pollution Bulletin, v. 29, p. 149-158.

Culbertson, C.W., Huntington, T.G., and Caldwell, J.M., 2007, Nutrient enrichment in estuaries from discharge of shallow groundwater, Mount Desert Island, Maine: U.S. Geological Survey Scientific Investigations Report 2007-5188, 34 p.

Davies, B.E., 1974, Loss-on-ignition as an estimate of soil organic matter.: Soil Science Society of America Proceedings, v. 38, p. 150-151.

Day, J.W., Jr., Hall, C.A.S., Kemp, W.M., and Yanez-Arancibia, A., 1989, Estuarine Ecology, John Wiley and Sons, New York. 558 pp.

D'Elia, C.F., Stuedler, P.A., and Corwin, N., 1977, Determination of total nitrogen in aqueous sampling using persulfate digestion: Limnology and Oceanography, v. 22, p. 760-764.

Doering, P.H., Roman, C.T., Beatty, L.L., Keller, A.A., and Oviatt, C.A., 1995, Water quality and habitat evaluation of Bass Harbor Marsh, Acadia National Park, Maine. Technical Report NPS/NESORNR/NRTR/95-31.

Duff, J.H., Pringle, C.M., and Tiska, F.J., 1996, Nitrate reduction in sediments of lowland tropical streams draining swamp forest in Costa Rica: An ecosystem perspective:

Biogeochemistry, v. 33, p. 179-196.

Farris, C.N., and Oviatt, C.A., 1999, Changes in metabolic rates under fluctuating salinity regimes for two subtidal estuarine habitats: Estuaries, v. 22, p. 126-137.

Fitch, R., Theodose, T., and Dionne, M., 2009, Relationships among Upland Development, Nitrogen, and Plant Community Composition in a Maine Salt Marsh: Wetlands, v. 29, no. 4, p. 1,179-1,188.

Furlong, E.T., Anderson, B.D., Werner, S.L., Soliven, P.P., Coffey, L.J., and Burkhardt, M.R., 2001, Methods of analysis by the U.S. Geological Survey National Water Quality

Laboratory-Determination of pesticides in water by graphitized carbon-based solid-phase 
extraction and high-performance liquid chromatography/mass spectrometry: U.S. Geological Survey Water-Resources Investigations Report 01-4134, 73 p.

Garbarino, J.R., Kanagy, L.K., and Cree, M.E., 2006, Determination of elements in naturalwater, biota, sediment and soil samples using collision/reaction cell inductively coupled plasma-mass spectrometry: U.S. Geological Survey Techniques and Methods, book 5, sec. B, chap. $1,88 \mathrm{p}$.

Gilbert, T.W., Behymer, T.D., and Castañeda, H.B., 1982, Determination of dissolved oxygen in natural and wastewaters: American Laboratory, v. 14, no. 3, p. 119-134.

Groffman, P.M., Altabet, M.A., Böhlke, J.K., Butterbach-Bahl, K., David, M.B., Firestone, M.K., Giblin, A.E., Kana, T.M., Nielsen, L.P., and Voytek, M.A., 2006, Methods for measuring denitrification: Diverse approaches to a difficult problem: Ecological Applications, v. 16, no. 6, p. 2,091-2,122.

Harvey, J.W., and Odum, W.E., 1990, The influence of tidal marshes on upland groundwater discharge to estuaries: Biogeochemistry, v. 10, p. 217-236.

Herbert, R.A., 1999, Nitrogen cycling in coastal marine ecosystems: FEMS Microbiology Review, v. 23, p. 563-590.

Howes, B.L., Weiskel, P.K., Goehringer, D.D., and Teal, J.M., 1996, Interception of freshwater and nitrogen transport from uplands to coastal waters-The role saltmarshes, in Nordstrom, K.F., and Roman, C.T., eds., Estuarine Shores--Evolution, environments and human alterations,: New York, Wiley, p. 287-310.

Huntington, T.G., Harden, J.W., Dabney, S.M., Marion, D.A., Alonso, C., Sharpe, J.M., and Fries, T.L., 1998, Soil, environmental, and watershed measurements in support of carbon cycling studies in northwestern Mississippi: U.S. Geological Survey, Open File Report 98-501, $91 \mathrm{p}$.

Jorgensen, K.S., and Sorenson, J., 1988, Two annual maxima of nitrate reduction and denitrification in estuarine sediments (Norsminde Fjord, Denmark): Marine Ecology Progress Series, v. 94, p. 267-274.

Kinney, E.H., and Roman, C.T., 1998, Response of primary producers to nutrient enrichment in a shallow estuary: Marine Ecology Progress Series, v. 163, p. 89-98.

Koch, M.S., Maltby, E., Oliver, G.A., and Bakker, S.A., 1992, Factors controlling denitrification rates of tidal mudflats and fringing salt marshes in south-west England: Estuarine, Coastal and Shelf Science, v. 34, no. 5, p. 471-485.

Meding, S.M., Morris, L.A., Hoover, C.M., Nutter, W.L., and Cabrera, M.L., 2001, Denitrification at a long-term forested land treatment system in the Piedmont of Georgia: Journal of Environmental Quality, v. 30, p. 1411-1420.

Murphy, J., and Riley, J.P., 1962, A modified single solution method for determination of phosphate in natural waters: Analytica Chemica Acta, v. 27, no. 31-36.

Nielsen, M.G., 2002a, Water budget for and nitrogen loads to Northeast Creek, Bar Harbor, Maine: U.S. Geological Survey Water-Resources Investigations Report 02-4000, 32 p.

Nielsen, M.G., 2002b, Estimating quantity of water in fractured bedrock units on Mount Desert Island, and estimated ground-water use, recharge, and dilution of nitrogen in septic waste in the Bar Harbor area, Maine: U.S. Geological Survey Open-File Report 02-435, 45 p.

Nielsen, M.G., Caldwell, J.M., Culbertson, C.W., and Handley, M., 2002, Hydrologic data collected in small watersheds on Mount Desert Island, Maine: 1999-2000. U.S. Geological Survey Open-File Report 02-416, 47 p. 
Nielsen, M.G., and Kahl, J.S., 2007, Nutrient export from watersheds on Mt. Desert Island, Maine, as a function of land use and fire history: Environmental Monitoring and Assessment, v. 126, p. 81-96.

NRC, 2000, Clean Coastal Waters: Understanding and Reducing the Effects of Nutrient Pollution. National Academy Press, Washington, DC., 428 pages.

Oremland, R.S., Umberger, C., Culbertson, C.W., and Smith, R.L., 1984, Denitrification in San Francisco Bay intertidal sediments: Applied and Environmental Microbiology, v. 47, no. 5, p. $1,106-1,112$.

Parton, W.J., Mosier, A.R., Ojima, D.S., Valentine, D.W., Schimel, D.S., Weier, K., and Kulmala, A.E., 1996, Generalized model for $\mathrm{N}_{2}$ and $\mathrm{N}_{2} \mathrm{O}$ production from nitrification and denitrification: Global Biogeochemical Cycles, v. 10, no. 3, p. 401-412.

Portnoy, J.W., Nowicki, B.L., Roman, C.T., and Urish, D.W., 1998, The discharge of nitratecontaminated groundwater from developed shoreline to marsh-fringed estuary: Water Resources Research, v. 34, no. 11, p. 3,095-3,104.

Reay, W.G., Gallagher, D.L., and Simmons, G.M.J., 1992, Groundwater discharge and its impact on surface water quality in a Chesapeake Bay inlet: Journal of the American Water Resources Association, v. 28, p. 1,121-1,134.

Roman, C.T., LaBash, C., Weber, J., and Rooney, S., 2001, Wetland and deepwater habitats, Northeast Creek (Mount Desert Island, Maine), Technical Report with Vegetation Map, U.S. National Park Service, Fort Collins, CO.

Scheiner, D., 1976, Determination of ammonia and Kjeldahl nitrogen by indophenol method: Water Research, v. 10, p. 31-36.

Seitzinger, S.P., 1988, Denitrification in freshwater and coastal marine ecosystems: ecological and geochemical significance: Limnology and Oceanography, v. 33, p. 702-724.

Seitzinger, S.P., and Kroeze, C., 1998, Global distribution of nitrous oxide production and N inputs in freshwater and coastal marine ecosystems: Global Biogeochemical Cycles, v. 12, p. 93-113.

Seitzinger, S.P., and Nixon, S.W., 1985, Eutrophication and the rate of denitrification and nitrous oxide production in coastal marine sediments: Limnology and Oceanography, v. 30, p. 1,332-1,339.

Seitzinger, S.P., Nixon, S.W., and Pilson, M.E.Q., 1984, Denitrification and nitrous oxide production in a coastal marine ecosystem: Limnology and Oceanography, v. 29, p. 73-83.

Silliman, B.R., and Bertness, M.D., 2004, Shoreline development drives invasion of Phragmites australis and the loss of plant diversity on New England salt marshes.: Conservation Biology v. 18, no. 5, p. 1,424-1,434.

Smith, C.J., Delaune, R.D., and Patrick, W.H., 1985, Fate of riverine nitrate entering an estuary: I Denitrification and nitrogen burial: Estuaries, v. 8, p. 15-21.

Tiedge, J.M., 1983 Denitrification. In A.L. Page and others, (eds.) Methods of soil analysis, Part 2. 2d ed. Agronomy 9:1011-1026.

Tobias, C.R., Harvey, J.W., and Anderson, I.C., 2001, Quantifying groundwater discharge through fringing wetlands to estuaries: Seasonal variability, methods comparison, and implications for wetland-estuary exchange: Limnology and Oceanography, v. 46, p. 604-615.

Valiela, I., and Bowen, J.L., 2002, Nitrogen sources to watersheds and estuaries: role of land cover mosaics and losses within watersheds: Environmental Pollution, v. 118, no. 2, p. 239-248. 
Valiela, I., Cole, M.L., McClelland, J., Hauxwell, J., Cebrian, J., and Joye, S., 2000, Role of Salt Marshes as Part of Coastal Landscapes, in Weinstein, M.P., and Kreeger, D.A., eds., Concepts and Controversies in Tidal Marsh Ecology: Dordrecht, Kluwer, p. 23-28.

Valiela, I., Costa, J., Foreman, K., Teal, J.M., Howes, B., and Aubrey, D., 1990, Transport of groundwater-borne nutrients from watersheds and their effects on coastal waters: Biogeochemistry, v. 10, p. 177-197.

Weier, K.L., Doran, J.W., Power, J.F., and Walters, D.T., 1993, Denitrification and the dinitrogen/nitrous oxide ratio as affected by soil water, available carbon, and nitrate: Soil Science Society of America Journal, v. 57, no. 1, p. 66-72.

Wigand, C., McKinney, R.A., Chintala, M.M., Charpetier, M.A., and Groffman, P.M., 2004, Denitrification enzyme activity of fringe salt marshes in New England (USA): Journal of Environmental Quality, v. 33, p. 1,144-1,151.

Wilde, F.D., variously dated, Field Measurements: U.S. Geological Survey Techniques of WaterResources Investigations, book 9, chap. A6, accessed april 20, 2011, at http://pubs.water.usgs.gov/twri9A/.

Wood, E.D., Armstrong, F.A.J., and Richards, F.A., 1967, Determination of nitrate in sea water by cadmium-copper reduction to nitrite: Journal of the Marine Biological Association of the United Kingdom, v. 47, p. 23-31. 
Prepared by the Pembroke Publishing Service Center.

For more information concerning this report, contact:

\section{Director}

U.S. Geological Survey

Maine Water Science Center

196 Whitten Road

Augusta, ME 04330

dc_me@usgs.gov

or visit our Web site at:

http://me.water.usgs.gov 
